\title{
Medievalista
}

Online

$25 \mid 2019$

Número 25

\section{A cozinha e a mesa em Loulé medieval nos seus utensílios de uso comum: o testemunho dos Inventários de Órfãos}

The kitchen and the table in medieval Loule through its common utensils: the testimony of the orphanological inventories

Iria Gonçalves

\section{OpenEdition}

Journals

\section{Edição electrónica}

URL: http://journals.openedition.org/medievalista/1729

DOI: 10.4000/medievalista.1729

ISSN: 1646-740X

\section{Editora}

Instituto de Estudos Medievais - FCSH-UNL

\section{Refêrencia eletrónica}

Iria Gonçalves, «A cozinha e a mesa em Loulé medieval nos seus utensílios de uso comum: o testemunho dos Inventários de Órfãos », Medievalista [Online], 25 | 2019, posto online no dia 17 março 2019, consultado no dia 01 maio 2019. URL : http://journals.openedition.org/medievalista/1729 DOI : 10.4000/medievalista. 1729

Este documento foi criado de forma automática no dia 1 Maio 2019

(C) IEM 


\section{A cozinha e a mesa em Loulé medieval nos seus utensílios de uso comum: o testemunho dos Inventários de Órfãos}

The kitchen and the table in medieval Loule through its common utensils: the testimony of the orphanological inventories

Iria Gonçalves

\section{NOTA DO EDITOR}

Data recepção do artigo / Received for publication: 05-12-2018

\section{I - Documentação disponível e suas dificuldades}

1 Não obstante a sua fragmentação e o facto de se encontrarem em algumas das suas partes em muito mau estado, tornando assim a sua leitura bem difícil ou até impossível, os documentos contidos no chamado Fundo do juiz dos órfãos de Loulé, que integra o acervo documental do Arquivo Histórico desta cidade ${ }^{1}$, são de um enorme interesse para o estudo da orfandade medieval e do cuidado que os poderes públicos colocavam na salvaguarda dos interesses dos menores que haviam perdido os seus naturais cuidadores, mas também para o de muitos outros assuntos, os mais variados, e não só para a história local. Sobretudo dentro do panorama da documentação medieval portuguesa, onde peças deste tipo constituem autênticas raridades.

2 É certo que o interesse primeiro que presidiu à feitura destes textos foi o de prestação de contas, por parte dos respectivos tutores, da maneira como administravam os bens dos tutelados sob a sua responsabilidade, mas os diversos passos dessa administração e dessa 
prestação de contas, a par da listagem dos bens, móveis como imóveis, podem ajudar a revelar aspectos muito interessantes, capazes de ilustrarem imensas facetas do viver medieval.

Neste ensaio apenas utilizarei a enumeração de alguns bens móveis que ficaram à morte dos pais dos órfãos: aqueles relacionados com a armazenagem, confecção e consumo dos alimentos.

4 Não se trata de uma grande colheita. São apenas dez os documentos que fornecem informações sobre esta matéria, abrangendo um período de mais de setenta anos do século XV, datado o primeiro de $1408^{2}$ e o último que aqui interessa de $1479^{3}$. Para mais, alguns desses inventários que nos restam encontram-se bastante danificados, impossibilitando a leitura de vários dos seus itens, o que, naturalmente, nos sonega parte da informação que anteriormente existia. E empobrece os resultados de qualquer análise. Além disso, só foi possível situar socialmente dois dos indivíduos a quem haviam pertencido os bens que aqui vão estar em causa: um João Gonçalves, que é dito carpinteiro ${ }^{4}$ e assim o sabemos integrado no grupo em regra numeroso e diversificado dos mesteirais, sempre que nos encontramos em ambientes urbanos, e um cavaleiro, Rui Lourenço o Velho ${ }^{5}$, com algumas presenças registadas nas actas das reuniões camarárias ${ }^{6}$, na sua qualidade de membro destacado dentro da sociedade louletana. Também apenas em relação a uma das famílias inventariadas há a certeza de que não se integrava em ambiente urbano: a de Pedro Afonso Carapeto, que morava em Castro Verde, termo da vila ${ }^{7}$. Haveria, talvez, alguns mais.

5 Com uma tão fraca colheita de elementos nestas vertentes, que, todavia, seria muito interessante explorar, nada do que pudesse ser dito resultaria sólido e até pertinente. Preferi, por isso, tratar toda a informação como um todo, realçando alguns aspectos particulares sempre que me pareceu necessário ou adequado.

6 Não obstante, os próprios inventários podem dar-nos umas quantas achegas, todavia nunca, ou raramente, de todo seguras, acerca das respectivas famílias e do seu posicionamento dentro da sociedade louletana da época. O mais ou menos volumoso património imóvel era, naturalmente, o mais importante, mas também o móvel, não só pelo número de utensílios referenciados - todavia este nem sempre possível de conhecer devido, como atrás referi, ao mau estado de conservação em que alguns dos documentos se encontravam - mas também pela raridade, qualidade e eventual requinte de alguns dos objectos arrolados.

7 Por tudo isto é possível apercebermo-nos de que todos os estratos da sociedade se encontram aqui presentes neste pequeno grupo de órfãos, talvez com excepção das famílias mais proeminentes da vila ${ }^{8}$, daquelas que mais assiduamente participavam na governação local. Mas restou informação bastante diferenciada, desde a proveniente de famílias gradas da sociedade, como o já referido cavaleiro Rui Lourenço o Velho, pertencente a uma nobreza de segundo plano, porque designado, algumas vezes, como fidalgo ${ }^{9}$ e cujo irmão fora alcaide do castelo da vila ${ }^{10}$ e cujos bens imóveis, que apenas sumariamente se encontram arrolados, mas que eram bastante numerosos e possuía algumas interessantes peças de prata além de vários outros objectos de algum requinte $\mathrm{e}$ únicos nesta série documental ${ }^{11}$, até às famílias mais desmunidas. Com efeito, alguns destes órfãos precisavam trabalhar para angariar o seu sustento ${ }^{12}$, o que, se não era caso raro na época, mas antes bastante frequente, era, no entanto, indiciador de famílias de reduzidos proventos. Mas o caso de pobreza que se me afigura mais gritante é o daqueles irmãos que ao dividirem os pouquíssimos e aparentemente pequeníssimos bens de raiz, o 
escrivão deixou expresso que "movell nom ho avia salluo hua almadraqueja velha"13. Isto é, uma pequena enxerga já velha era todo o móvel daquela casa que o escrivão encontrou ${ }^{14}$. Considerando embora que alguns artefactos pudessem ter sido desviados para se eximirem à partilha, estes nunca poderiam ter deixado a casa tão desguarnecida se, à partida, tivessem tido os mínimos indispensáveis ao desenrolar de um quotidiano familiar normal, nem sequer para os escalões mais baixos da sociedade, de acordo com os padrões da época. A vizinhança lá estaria, conhecedora, como todos eram, das condições de vida de todos, pronta a querer saber, e sobretudo a comentar. O que, no caso, poderia ter algumas consequências pouco agradáveis. Dispersos, assim, estes inventários, pelos variados estratos socioeconómicos urbanos e, possivelmente, campesinos, eles não passam de uma amostragem exemplificativa.

8 Assim sendo, não vale a pena tentar analisar sectorialmente, porque nada do que pudesse ser dito resultaria com um mínimo de solidez. Preferi, por isso, e como indiquei, tratar toda a informação como um todo, realçando alguns aspectos particulares mais significativos, sempre que se me afigurou pertinente.

9 Para lá das dificuldades que esta série em especial apresenta, outras ainda se perfilam, mais latas, comuns a toda a documentação deste tipo e generalizadamente encontradas pelos investigadores interessados, em diversos lugares da Europa: a falta de utensílios em princípio indispensáveis em qualquer habitação, por muito pobre que ela fosse ${ }^{15}$. Porque, em verdade, são em regra objectos pequenos, de pouco ou nenhum valor monetário, perecíveis com muita facilidade, os que se encontram, com mais frequência, ausentes dos inventários. Como um dos exemplos mais gritantes poderei citar as colheres de pau, indispensáveis em qualquer cozinha para mexer os alimentos que servem ao lume e que em regra, como nesta série que me proponho analisar, se encontram omissas ${ }^{16}$. Mas que, no entanto, até, eventualmente, algum membro da família poderia moldar, a partir de qualquer desprezado tronco de árvore sem despender valor algum, monetário ou outro ${ }^{17}$. Aliás, nesta mesma série em que me proponho apoiar, no maior dos inventários em presença - no do cavaleiro atrás referido - diz-se, a determinada altura da enumeração: "Jtem bacias e caldeiras e outras pessas de casa meudas" ${ }^{18}$. 0 que claramente mostra que existe aí - e muito possivelmente em outros casos, talvez em todos - a omissão de um número mais ou menos alargado de objectos, omissão assumida pelo escrivão e, sem dúvida, pelos demais presentes ao acto.

10 A falta de utensílios de insignificante valor monetário mesmo para a época e ainda de outros facilmente deterioráveis, como é o caso dos objectos de cerâmica, é compreensível, sobretudo quando se trata, como aqui, de inventários orfanológicos. Por eles devia o tutor, anos mais tarde, por vezes bastantes anos mais tarde, prestar contas da sua tutoria ${ }^{19}$. É certo que em determinados casos, os bens pertencentes aos órfãos eram vendidos em hasta pública ${ }^{20}$, mas nem sempre isso acontecia, até porque, ocasionalmente, o facto talvez inviabilizasse a continuação do normal funcionamento da habitação. Assim era melhor que eles, esses utensílios, ficassem esquecidos. Isto quando, feitos que eram alguns inventários muito tempo após a morte daquele que dera lugar à sua feitura ${ }^{21}, \mathrm{o}$ que, no entanto, a lei desaprovava ${ }^{22}$, vários objectos poderiam já ter sido alienados, sonegados, completamente deteriorados ou de algum outro modo desaparecidos. $\mathrm{E}$ a lei era muito clara nesse sentido.

11 É certo que as disposições legais eram muitas vezes esquecidas ou ignoradas, sobretudo em locais, como Loulé, distanciados dos caminhos costumeiros da itinerância régia. Mas 
havia sempre a possibilidade de que essa lei se viesse a tornar operante, com consequências desagradáveis ${ }^{23}$. Era melhor prevenir, fazendo desaparecer, ao menos da escrita, os artefactos mais frágeis. Por isso qualquer análise que dos inventários resulte, ficará sempre empobrecida.

Neste ensaio, para de algum modo compensar aquelas perdas, tentarei apelar para outras áreas do conhecimento, de que a arqueologia será uma das mais importantes, mas também a etnologia. No entanto, é sabido que a arqueologia também enfrenta dificuldades várias.

É certo que os arqueólogos têm exumado biliões de fragmentos cerâmicos, entre outros restos para aqui menos interessantes, mas faltam-lhes objectos de madeira e de metal. Os primeiros porque em regra se degradam e desaparecem nos contextos em que foram sepultados. Quando, porém, esses contextos são bastante húmidos e, portanto, propícios à conservação da madeira, tais objectos podem contar-se por muitas dezenas ${ }^{24}$, o que enriquece a informação disponível. Todavia, e tanto quanto sei, não para Loulé. Na verdade, são muito poucas as jazidas arqueológicas a apresentarem aquelas condições.

Mais ausentes ainda estão os segundos, os objectos metálicos. Todo o metal era reutilizado porque sempre tinha valor ${ }^{25}$. Os metais nobres, para a presente análise pouco significativos, tinham o seu valor intrínseco, como afinal pelos séculos fora, até hoje; os outros, desmembrados, fragmentados, havia sempre um ferreiro ou outro profissional afim capaz de lhes dar uma vida nova na forma de um outro utensílio. Desaparecem das jazidas arqueológicas mas, em regra, marcam presença nos inventários. Neste sentido, as informações provenientes de ambas as vertentes de certo modo se complementam. Neste como noutros temas de estudo podem ser preciosos os elementos que a arqueologia coloca ao nosso dispor.

Por outro lado a etnologia e até a antropologia, embora de forma mais subtil, podem também prestar ajudas de enorme valia. Costumes arreigados que passam nas famílias de geração em geração podem, ao menos em aldeias mais ou menos recônditas, chegar muito próximo dos nossos dias e ter sido observadas até por alguns de nós mas sobretudo pelos nossos pais e avós. De uma maneira geral a transmissão ao longo das gerações afigura-se fiel ${ }^{26}$.

O domínio da alimentação, no caso vertente da alimentação medieval, é talvez um dos que mais podem lucrar com os conhecimentos provenientes daquelas áreas do saber. Tentarei chamá-las em meu auxílio sempre que me pareça pertinente.

\section{II - A COZINHA}

\section{Antes de cozinhar. o armazenamento}

17 Sobretudo no campo, mas também no mundo urbano, os víveres, com a sazonalidade que muitos deles conhecem, de uma forma muito acentuada os de origem vegetal, tinham a sua época específica para o abastecimento das famílias. Quer esses víveres fossem de produção própria e nesse caso chegada a altura da maturação tinham que se apanhados e recolhidos; quer fossem de produção alheia porque, sobretudo para as famílias abastadas e que dispunham da liquidez necessária, era mais conveniente abastecerem-se por altura das colheitas, quando os produtos eram mais abundantes e os preços mais convidativos, as compras faziam-se por grosso, o que podia ser apenas uma vez por ano. Facto que se 
tornava muito significativo no caso dos cereais ${ }^{27}$, mas também do azeite. Não assim do vinho que, na Idade Média, se deteriorava com muita facilidade e rapidez. Mas também ele se conservava em casa durante meses, enquanto ia sendo consumido.

Outros produtos conheciam também abastecimentos assaz volumosos, que era preciso gerir ao longo de vários meses ou durante todo o ano. Era necessário existirem em casa contentores de vários tipos e tamanhos, capazes de armazenar os alimentos, conservando-os durante o tempo necessário em boas condições de consumo.

19 Para os líquidos - sobretudo vinho e azeite - talhas ${ }^{28}$, potes ${ }^{29}$, em boa parte dos casos com a especificação, para umas e outros, de que se destinavam a conter vinho ${ }^{30}$ ou azeite ${ }^{31}$, estavam presentes na maioria dos recheios domésticos. Mas não em todos ou, pelo menos, não em todos em número suficiente, pois algumas famílias precisavam de alugar, tanto potes como talhas, o que a fonte em análise documenta ${ }^{32}$.

As pipas seriam menos comuns, presentes, nesta fonte, em uma única morada e representadas, aí, por um único exemplar, no caso contendo vinagre ${ }^{33}$. Por sua vez, os cântaros, que aparentemente deviam ser artefactos comuns ${ }^{34}$, não deixaram qualquer registo nos inventários em análise.

21 Também não muito comuns eram as jarras, destinadas, como as talhas, a conter vinho ${ }^{35} \mathrm{e}$ azeite $^{36}$. Mas estas talvez fossem contentores pequenos, próprios não para armazenar, mas para conter a porção de líquido que na altura se encontrava a ser usada, mas não em serviço: de mesa, como seria o caso do vinho, ou no tempero dos alimentos já cozinhados para o caso do azeite. No entanto, a forma como a documentação no-las apresenta - jarra de ter vinho/azeite -, é a mesma que se encontra consagrada para os contentores. Seriam, talvez, vasilhas intermédias entre aquelas que se destinavam a conter a colheita própria ou os grandes aprovisionamentos, que se guardariam em adegas ou celeiros, e as de uso quotidiano na cozinha e à mesa.

22 Não pude encontrar resposta para esta questão, resposta que talvez possa ser dada pela arqueologia, por meio do confronto entre capacidades de recipientes e análises químicas sobre os produtos que contiveram.

23 Como outros investigadores, também não encontrei vasilhas destinadas ao armazenamento de água ${ }^{37}$, sempre indispensável em qualquer casa para os mais diversos fins. $O$ abastecimento poderia ser feito aquando da sua utilização e o transporte para casa em qualquer contentor destinado a líquidos, como aventam alguns investigadores ${ }^{38}$. Só que é um pouco difícil de compreender, sobretudo quando se tratava de famílias mais abastadas e mais exigentes ${ }^{39}$.

24 Os víveres sólidos eram mais fáceis de armazenar, sobretudo quando não em grandes quantidades, mas precisavam de um contentor, embora pudessem ser menos selectivos que os líquidos. Assim lhes serviam as mesmas talhas ${ }^{40}$, potes ${ }^{41}$, jarras, mas também arcas ${ }^{42}$, $\operatorname{sacos}^{43}$, seirões ${ }^{44}$.

Alguns potes com asas múltiplas - quatro, seis - sugerem mesmo a sua utilização como contentores de carne ou outros alimentos do género, quer crus, quer branqueados e envoltos em banha, azeite ou mel, conforme os casos, quer, até, já cozinhados. Podiam com facilidade suspender-se dos barrotes do tecto, de modo a colocá-los fora do alcance de quaisquer roedores ${ }^{45}$. 


\section{A preparação dos víveres para a cozedura}

É claro que antes de se passar à confecção propriamente dita, os víveres tinham de ser preparados, operação mais ou menos longa, mais ou menos fácil e rápida, de acordo com o produto a cozinhar e com a receita que iria ser executada.

A operação mais demorada e exigente, a necessitar de vários passos desenrolados em sequência bem definida, cada um deles a necessitar de apetrechos diferentes, era o pão. É certo que em todas as cidades e vilas funcionava um corpo de padeiras rigidamente controladas, no desempenho da profissão pelos almotacés, que se comprometia a colocar diariamente à venda o pão necessário aos naturais e forasteiros que quisessem adquiri-lo. E para lá desse corpo, em Loulé, ao menos na primeira metade do século XIV, laborava uma padeira franqueada, isto é, não sujeita ao apertado controlo dos almotacés e ao pagamento de multas resultante de eventuais falhas no fabrico do pão e no respectivo peso, mas cuja obrigação era a de confeccionar "boo pam branco stremado e bem fecto", destinado, de um modo especial "as gentes stranheiras e homens onrados" ${ }^{46}$. Isto é, àqueles que o podiam pagar. Deste modo a vila encontrava-se bem abastecida em pão $\mathrm{e}$ para todas as bolsas.

Não obstante, a maior parte das famílias preparava o seu pão em casa, levando-o depois a cozer num forno público. Para isso havia que, em primeiro lugar, peneirar a farinha vinda do moinho, peneiração que podia ser feita uma única vez, por peneira de malha mais larga - peneira de rara ou de rala - ou por mais de uma vez, agora usando uma peneira mais fina - peneira de ante-mão - ou mais apertada ainda - peneira de alva - de modo a obter um pó leve e fino, propiciador de uma massa mais branca e fofa ${ }^{47}$.

Devia ser esta última a massa do pão resultante do trabalho executado por aquela padeira franqueada a que acima fiz referência, mas não o que se confeccionava na generalidade das habitações louletanas ou o que era diariamente posto à venda e destinado ao comum da população. No entanto, pelo menos uma peneira era sempre indispensável para o trabalho. Porém, nem todos os inventários mencionam este artefacto $^{48} \mathrm{e}$ só em um deles ficaram registadas duas peneiras, aliás, à época, já velhas ${ }^{49}$.

Expurgada a farinha na medida em que se pretendia, passava-se à amassadura. Em princípio esta devia ser feita numa masseira, objecto que diversos investigadores têm encontrado de forma muito generalizada ${ }^{50}$, mas que em Loulé, aparentemente, devia ser raro, na medida em que nenhum destes inventários o menciona. 0 pão devia amassar-se num alguidar talvez usado também para outros fins ${ }^{51}$, uma vez que esta alfaia, susceptível de tal utilização, se encontrava em quase todas as casas e por vezes representada por diversos exemplares ${ }^{52}$, eventualmente usados para diversas funções, de acordo com o seu tamanho, com o material em que haviam sido confeccionados, com a maior ou menor preocupação relativa aos acabamentos - cerâmicas vidradas ou não, por exemplo ${ }^{53}$ - ou com quaisquer outras características.

31 É natural que também se utilizasse para o mesmo fim uma gamela - que podia até ser dita gamela de pão ${ }^{54}-$, artefacto que, além do mais, era um dos que constavam no chamado foral novo da vila, entre os objectos de madeira que não pagavam portagem ${ }^{55}$.

Em uma ou outra daquelas alfaias se amassava o pão, na cozinha, quando esta se apresentava como uma divisão autónoma dentro do espaço habitacional, ou ao canto da 
lareira quando se tratava de uma moradia unicelular, porque esse era o lugar mais abrigado e quente dentro da habitação e aí a massa levedava melhor.

Durante o trabalho a massa ia-se colando às paredes do alguidar ou gamela onde o processo decorria e era preciso despegá-la porque tudo havia de ficar bem amalgamado e nenhum pedaço se podia perder. Para isso havia em algumas habitações um rapadouro, ou rapadeira ${ }^{56}$.

Levedada a massa era agora necessário tendê-la em porções equivalentes ao tamanho dos pães que se pretendiam obter, quase sempre grandes, na Idade Média. Essa operação era executada sobre uma simples tábua ${ }^{57}$, ou num tabuleiro especificamente usado para o efeito ${ }^{58}$, utensílios nos quais se transportava o pão para o forno e neles voltava para casa, já cozido ${ }^{59}$. Em moradas de maior requinte podia haver toalhas de qualidade - de lenço, um tecido fino e caro - para o $\operatorname{tapar}^{60}$ e assim evitar que ele fosse conspurcado com qualquer sujidade ${ }^{61}$. Foram estes os apetrechos que se revelaram mais comuns nas casas louletanas, a mostrar, também por esta via, a enorme importância do pão no regime alimentar medieval. Todos os outros víveres eram menos exigentes no que se refere à preparação para a cozedura.

35 A lavagem era indispensável a todos ou, pelo menos, a quase todos, operação que se realizava em bacios ou bacias de cerâmica ou de latão, mas que em poucos recheios domésticos se encontram mencionados, embora em alguns pudessem existir representados por mais do que um exemplar ${ }^{62}$. Mas claro que se utilizavam para o efeito os alguidares acima mencionados, sobretudo os de cerâmica vidrada e, por isso, estanques.

Um outro utensílio utilizado na preparação dos alimentos e indispensável para muitos deles - a faca de cozinha - encontra-se de todo ausente e tem-se revelado rara em outros contextos $^{63}$. Utilizar-se-ia para o efeito qualquer instrumento cortante, inclusive uma navalha ou mesmo uma arma tipo punhal, objectos que, por serem de uso pessoal, não integrariam um inventário como estes em que me estou a apoiar, a não ser, para o caso das armas, de inventários no feminino.

Utensílios para cortar pedaços de carne com os respectivos ossos, susceptíveis de poderem ser introduzidos nos recipientes onde seriam cozinhados, estão também ausentes destes textos. Usar-se-ia, de igual modo, qualquer instrumento cortante que, neste caso, até poderia ser uma ferramenta artesanal, como um pequeno machado de utilização variada. Numa Idade Média onde os bens materiais de toda a sorte não abundavam era preciso usar os existentes de todas as formas possíveis.

\section{Os víveres sobre o fogo}

\section{O fogo}

38 Antes de começar a cozedura de qualquer alimento era preciso acender o lume. Tarefa nada fácil na época aqui tratada e que continuou a não o ser ao longo de vários séculos e até época bastante próxima de nós ${ }^{64}$.

39 Normalmente obtinha-se o fogo pela friç̧ão de um fuzil confeccionado a partir de um metal rico em carbono, com uma pedra de sílex, acção da qual resultavam faúlhas que se projectavam sobre uma matéria inflamável, preparada para o efeito ${ }^{65}$. 
40 Mais uma vez, em nenhuma destas moradias se encontrava, de que tivesse ficado memória, qualquer objecto destinado ao fogo, quer à sua produção - fuzil ou pederneira quer à sua manipulação - tenaz ou pá de fogo. Se estas últimas ainda podiam dispensar-se, substituídas pelos próprios troncos que ardiam ou iriam arder, não assim os primeiros. Mais uma vez podia pedir-se lume numa casa vizinha, o que aconteceu com frequência até à generalização dos fósforos seguros, mas teria de haver sempre alguém a possuir os instrumentos necessários à produção do fogo.

41 Este acendia-se no chão e sobre ele, ou ao lado, colocavam-se os utensílios necessários à cozedura. Em nenhum dos inventários ficou assinalada a existência de trempe ou cremalheira $^{66}$, pelo que se tornava impossível a colocação de qualquer peça de barro ou metal sobre os troncos de madeira em combustão. Se assim era - ou onde assim era tornar-se-ia necessário acomodar a vasilha ao lado do fogo até se produzirem brasas em volume suficiente para sobre elas se poder colocar, em posição de equilíbrio, a peça de loiça que continha os alimentos a cozinhar. Para que esse equilíbrio resultasse mais fácil, algumas das alfaias tinham o fundo levemente convexo ${ }^{67}$.

\section{Os cozidos}

42 Já diversos investigadores interessados em assuntos relativos à alimentação medieval têm verificado que a técnica culinária mais utilizada na época era a que se processava dentro de um líquido levado à ebulição, líquido esse que era quase sempre a água. Nas casas pouco abonadas, essa operação usava-se com bastante insistência ${ }^{68}$ para a confecção de caldos, onde podia entrar uma enorme multiplicidade de ingredientes. Eram, em primeiro lugar, hortaliças e legumes, verdes ou secos, que todos contavam já, à época, um número muitíssimo elevado de espécies cultivares, mas eram também cereais, em grão ou farinados; eram alguns frutos, sobretudo a castanha e a bolota, esta, especialmente a de azinheira ${ }^{69}$; eram ainda carnes, frescas ou salgadas. Estas, aliás, também nas grandes casas se serviam, na maior parte das vezes, apenas cozidas, sobretudo as que provinham dos animais do rebanho ${ }^{70}$. As carnes que também aí muitas vezes se levavam à mesa, nomeadamente as de bovino, eram já de animais não muito jovens, quando não já mesmo velhos $^{71}$, e por isso a cozedura em água ou num caldo era a técnica culinária que melhor se lhes adequava. Nem que fosse apenas para um branqueamento prévio à continuação da receita que se pretendia executar.

Eram precisas panelas ou quaisquer outros recipientes que as pudessem substituir, alfaias essas que deviam ter, na maior parte das casas, utilização muito frequente. É certo que alguns investigadores apontam diversos utensílios para a confecção desses caldos, como potes, caldeiras, caldeirões, eventualmente com cobertura ${ }^{72}$, mas sem dúvida que as panelas eram e continuaram a ser, pelos tempos fora, os mais comuns. Todavia só em um dos recheios domésticos ficou registada a existência de panelas, em número de três, com a indicação de serem de barro ${ }^{73}$.

Panelas de barro, as mais comuns e baratas, muito mais que as de metal. E que não faltavam em Loulé. A vila era auto-suficiente em loiça de barro ${ }^{74}$, como, aliás, o deviam ser todas as cidades e vilas do Sul de Portugal, todas elas albergando comunidades mais ou menos importantes e numerosas de mudéjares, tantos deles dedicados à olaria ${ }^{75}$. Mas se alguém preferisse uma panela de outras proveniências também não teria dificuldade em encontrá-la. Elas deviam ser comuns, essas peças, taxadas como estavam pela câmara municipal ${ }^{76}$. 


\section{quando isso acontece elas são ditas de Málaga ${ }^{82}$, portanto uma loiça de qualidade, mais} própria para ir à mesa e assim dificilmente usada para se expor directamente ao fogo. É mais provável que a cozedura se processasse em alguns daqueles bacios a que atrás me referi, por certo especialmente reservados para o efeito e outros semelhantes. Aliás a arqueologia tem disponibilizado, em terras algarvias, quantidade de fragmentos cerâmicos pertencentes a alfaias - chamam-se tigelas, bacios, malgas, que todas elas apresentam formas semelhantes -, alguns deles com evidentes sinais de exposição ao fogo, podendo corresponder a alguma coisa de parecido com aquelas tigelas da listagem louletana ${ }^{83}$. Naturalmente outros víveres aí podiam ser cozidos, como, por exemplo, ovos, comuns na época e servidos com essa preparação na generalidade das casas.

\section{Os fritos e os assados}

49 Alguns investigadores, é certo que fora de Portugal, têm verificado que a frigideira - a sertã - era um utensílio de cozinha muito usual, com presença na maioria das casas, por vezes representada por vários exemplares e até acompanhada com uma espátula destinada a virar o alimento que cozia na gordura ${ }^{84}$. Pôde mesmo ser qualificada como uma das rainhas da cozinha ${ }^{85}$. Por outro lado, sabe-se que, pelo menos o peixe, era muitas vezes frito em azeite, após previamente envolvido em farinha e talvez temperado, para lá do sal, com salsa e um acidulante que poderia ser o vinagre ou o sumo da laranja azeda. Pela sua simplicidade e custo moderado, a receita era acessível a todos, o que não a impedia de ser servida nas grandes casas, sem exclusão da corte régia ${ }^{86}$. Por outro lado, não só os espólios arqueológicos algarvios têm revelado a existência de sertãs de cerâmica ${ }^{87}$, como também estes artefactos foram contemplados na lista louletana de peças de olaria, a que já por diversas vezes me referi ${ }^{88}$.

Existiriam sertãs, ao menos de cerâmica, em diversas moradias louletanas e nas mais abastadas poderiam ser, inclusive, de metal. Ora, em nenhum dos inventários que nos ficaram se declarou esse utensílio de cozinha. Possivelmente em nenhuma daquelas 
habitações existiria uma sertã metálica, de cobre ou, sequer, de ferro, mas existiria, em algumas delas, uma frigideira de barro, vidrada, esquecida pelo escrivão. Penso que é oportuno lembrar aqui, mais uma vez, as omissões explicitamente assumidas por aquele oficial concelhio, ao redigir o inventário realizado após a morte do cavaleiro Rui Lourenço o Velho, já atrás referida ${ }^{89}$. Explicitadas aqui, tais omissões tiveram lugar, sem dúvida, em vários outros casos em que não se julgou oportuno deixá-las registadas.

51 Todavia, em relação a esta alfaia em concreto, talvez os hábitos culinários da região não privilegiassem os fritos, o que de certo modo ajudaria a compreender a falta deste artefacto, em outras regiões tão presente, como atrás ficou lembrado. Ao contrário da fritura, o assado revelou-se como bastante frequente entre os louletanos.

Pelo que até agora se tem apurado no respeitante à cozedura por exposição directa ao fogo, sobretudo tratando-se da carne, as condições e os hábitos deviam ser bastante diferentes de umas regiões para outras. É certo que um assado só resulta bem quando praticado sobre carnes tenras. Ao menos segundo os conceitos e os gostos actuais. Por isso, diversos investigadores se têm pronunciado no sentido de que estes pratos estavam, por assim dizer, reservados às grandes casas, às famílias possidentes que com frequência consumiam animais juvenis, o que é apoiado pela raridade de espetos, mas sobretudo de grelhas, na documentação medieval. Em determinados contextos geográficos ${ }^{90}$, que não em todos ${ }^{91}$.

Em Loulé, as grelhas deviam ser raras e nenhuma ficou registada na documentação que tem servido de apoio a estas páginas, mas os espetos eram muito comuns, ausentes apenas em duas das moradias inventariadas - não das mais pobres - e sempre mais do que um exemplar. Espetos grandes e espetos pequenos, por certo todos de ferro, embora só em um dos inventários com essa caracterização ${ }^{92}$. Com frequência existiam em número de quatro e cinco. $O$ que só pode significar uma utilização muito frequente desses utensílios.

Todavia, a distinção que é feita entre grandes e pequenos - em menor número os primeiros, em maior os segundos - talvez mereça alguma reflexão. Que espetos seriam estes? Poderíamos pensar que os maiores se destinariam a assar grandes peças de carne e os outros pequenos animais ou pedaços de carne. Aliás, tem-se considerado que eles se destinavam sobretudo a cozinhar aves e peças de caça que, é sabido, se consumiam muitas vezes cozinhadas dessa forma ${ }^{93}$. Porém aqui, em Loulé, a distinção entre espetos maiores e menores talvez fosse um pouco diferente.

Estes recheios domésticos inventariados pertenciam a casas de gente comum, tanto quanto é possível perceber habitadas por famílias nucleares e portanto abrigando e servindo um pequeno grupo de pessoas. Não haveria ocasião, ou raríssimas vezes haveria, para a utilização de um grande espeto, capaz de proporcionar o assado de um animal, sequer de médio porte. Penso que os maiores espetos dos louletanos seriam utilizados para assar uma galinha, uma ou duas perdizes, um pato, um coelho, uma lebre, isto é, aves e caça miúda sobretudo. Mas por certo um espeto de rodar, o que tornava a preparação mais fácil e perfeita. Os pequenos seriam talvez uma simples varinha de ferro, pontiaguda, onde se enfiavam peixe ou pedaços de carne ${ }^{94}$. Aliás, deviam encontrar-se com facilidade por todo o lado, dada a frequência com que a documentação medieval, até a menos vocacionada para isso, refere os assados. Como exemplo, pode citar-se Fernão Lopes. Conta-nos o cronista que quando os castelhanos cercavam Lisboa, em 1384, sabendo de uma investida preparada pelos portugueses a partir da cidade, com tanta pressa abandonaram as aldeias dos arredores que tinham ocupado, que os de Lisboa as acharam "desamparadas delles, e as panellas ao fogo, e os espetos com carne, que nom 
ouverõ vagar de comer com trigança de sua partida" ${ }^{95}$. Podem citar-se também refeições vulgares onde o assado estava presente. Em jantares colectivos organizados por algumas confrarias faziam-se espetadas e assaduras ${ }^{96}$; em determinadas refeições obrigatoriamente servidas aos mordomos régios de Entre-Douro-e-Minho, quando se deslocavam em serviço, um dos pratos teria de ser de carneiro assado ${ }^{97}$. Era, assim, uma técnica culinária aparentemente possível em todas as cozinhas. Com certeza praticada com frequência na generalidade das moradas louletanas.

\section{Alguns requintes culinários?}

A partir da documentação a que tenho estado a recorrer, pouco mais se pode dizer sobre outras técnicas usadas na cozinha, nomeadamente os estufados que, sem dúvida, também se praticavam em Loulé, ao menos nas casas mais exigentes.

Todavia, alguma coisa poderá deduzir-se sobre o que seria feito para melhorar e diferenciar o sabor dos alimentos previamente cozidos ou assados. 0 que não podia deixar de acontecer numa vila como Loulé de finais da Idade Média.

Inscrita que estava, como é sabido, nos grandes circuitos internacionais de comércio por meio da exportação dos seus frutos secos e pela necessidade de importar cereais; situada num nó de trânsito entre o Barlavento e o Sotavento algarvios, ligando toda a região ao resto do País e ao exterior ${ }^{98}$, Loulé chamava a si gentes de proveniência vária, gentes, muitas delas, habituadas ao melhor que a época podia oferecer - alguns mercadores de grosso trato que vinham negociar os frutos secos, por exemplo. Por outro lado, uma elite de "notáveis" bastante significativa9" - entre os quais se contava uma nobreza de segundo plano - ligados, muitos dos seus membros, àquela faixa de comércio internacional como produtores e talvez como intermediários, com terras mais ou menos dilatadas, mas usufruindo de rendimentos não despiciendos, todos eles contribuíam para introduzir na sociedade alguns gostos mais requintados.

No dizer de Luís Miguel Duarte, nesta época, em Loulé, "sente-se uma terra animada, quase rica, com uma produção agrícola virada para a exportação e um crescimento demográfico interessante" ${ }^{100}$.

Tudo isso contribuía para apurar gostos, trazer exigências novas, aumentar a procura da qualidade e da diversidade. Também, como é óbvio, no campo alimentar. Fenómeno que, começando sempre pelas elites, se vai desenrolando depois, em cascata, a toda a sociedade. E em cada lugar vão-se seguindo as modas vigentes de acordo com as condições que se possuem e introduzindo as modificações necessárias. Aqui em Loulé, como, aliás, em toda a parte neste final da Idade Média, os requintes da gente comum, em termos de culinária e a avaliar pelas alfaias documentadas, pouco ultrapassariam os temperos, nomeadamente os molhos.

61 Claro que não sabemos como as donas de casa temperavam os seus pratos - para lá dos consabidos sal e uma gordura - nem que molhos preparavam. Mas sabemos que o faziam e como podiam fazê-lo. Porque o utensílio básico para a preparação dos molhos, esse era comum e existia, se não em todas as casas, em muitas delas: o almofariz.

Na verdade o almofariz - o gral, na terminologia mais usada na época -, como um pouco por todo o lado ${ }^{101}$, era um utensílio comum nas moradas louletanas, por vezes representado por mais do que uma unidade, confeccionado em pedra ou numa madeira dura ${ }^{102}$. 
63 É sabido como a sua utilização era indispensável para a preparação de medicamentos e que muitos deles se faziam em casa e assim acontecia também em Loulé, sem dúvida. Mas era-o do mesmo modo para a confecção de molhos. É certo, como acima disse, que não possuímos receitas dessas preparações, mas, em termos gerais, sabemos como eram confeccionadas.

64 Se nas grandes casas eles eram feitos à base de especiarias, também se lhes juntavam ervas aromáticas utilizando um larguíssimo espectro ${ }^{103}$, se regavam com um líquido que podia ser leite de amêndoa, mas também um caldo ou um acidulante e se espessavam com miolo de pão. Muitas receitas incluídas nos variados livros de cozinha que a Baixa Idade Média produziu e chegaram até nós apontam, em todo o lado, para estes ingredientes. Ora bem, aqui, em Loulé, essas receitas tinham que sofrer algumas adaptações.

As famílias mais possidentes tinham acesso àquilo que na cidade e vilas de alguma importância se transaccionava como especiarias: os chamados "pós", uma mistura de plantas diversas, moídas, talvez com alguma percentagem daquelas que vinham do Oriente, mas não especiarias puras. É possível que também algumas destas se encontrassem à venda em Loulé, mas só eram acessíveis às famílias mais ricas.

Com algumas especiarias ou sem elas, com aqueles "pós" ou sem eles, não havia dificuldade em encontrar, tanto na flora cultivada como na silvestre, uma enorme variedade de plantas desde tempos imemoriais usadas como condimento ${ }^{104}$. Mas o próprio foral louletano de Quinhentos contempla também, como o de Silves e os demais dados ao Algarve $^{105}$, a entrada na vila de erva-doce, coentro seco, água rosada, água de flor de laranja ${ }^{106}$. Tudo temperos fáceis de encontrar em Loulé. $\mathrm{E}$ ainda, pelo menos a partir de 1403, habitava na própria vila um homem que confeccionava molho de mostarda e, naturalmente, o comercializava ${ }^{107}$.

67 Bastava, pois, reunir o grupo de condimentos requeridos ou possíveis no momento, esmagar e moer tudo no almofariz até obter uma consistência fina e homogénea, regar com um caldo ou um acidulante - vinagre ou agraço, ambos fáceis de obter porque derivados do sumo da uva - e espessar com miolo de pão. Poucas famílias, em Loulé, estariam arredadas deste tipo de consumo.

68 Aliás, sabemos como o almofariz era alfaia insistentemente usada, não só pela sua presença na generalidade das casas, mas também pelo acentuado desgaste que alguns deles, recuperados pela arqueologia, têm mostrado ${ }^{108}$.

Estas confecções eram a forma de melhorar e diversificar os sabores de uma alimentação monótona, porque feita à base de cozidos e assados. Não podiam deixar de ser praticados.

Como última nota de algum possível requinte na cozinha, apenas poderei citar a existência, em uma das moradias, de um atanor de barro ${ }^{109}$, um fogareiro ${ }^{110}$, onde os assados na brasa estariam facilitados e resultariam mais perfeitos; onde seria mais fácil equilibrar todos os recipientes e onde até a velha tradição saída dos mosteiros de, no Inverno, aquecer o vinho que se bebia ${ }^{111}$, era mais fácil. E não seria aquele o único exemplar existente em Loulé.

\section{Cozinhar sem o uso de alfaias}

71 A par de todas estas confecções, sem dúvida as mais numerosas, que não dispensavam o uso de qualquer utensílio no decorrer da sua preparação, outras havia que podiam prescindir de tudo, excepto, como é óbvio, do próprio alimento. 
72 Estavam neste caso, em primeiro lugar, as refeições frias, que eram praticadas pelos camponeses quando trabalhavam em agros longe da sua casa, mas também pelos citadinos mais desmunidos trabalhando igualmente distante de casa, ou, para estes últimos, quando a lenha escasseava para iluminar a lareira e aquecer tudo à sua volta. Porque em qualquer aglomeração urbana a lenha era cara e na maior parte dos casos apanhá-la gratuitamente já não era possível, ou tornara-se muito difícil.

73 Acontecia o mesmo em todo o país - em toda a parte - e, na circunstância, cada região valorizava ao máximo os seus principais recursos. Claro que na época, em qualquer lugar, o pão se encontrava na primeira linha. Uma fatia de pão com uma talhada de queijo, umas azeitonas curtidas ou, na sua falta, um vegetal, mesmo em cru - e nesta vertente as cebolas eram as preferidas - podia resultar, para os mais pobres, uma refeição aceitável. Como, na verdade, continuou a acontecer pelos tempos fora, até bem próximo de nós ${ }^{112}$. Em Loulé, um recurso endógeno e rico era, no caso, da maior importância: os seus figos, frescos, mas sobretudo secos, até porque podiam ser consumidos pelo ano adiante. $\mathrm{O}$ sentido de muitas das preocupações dos homens-bons da terra, daqueles que na localidade exerciam o poder, é bastante significativo. Porque não era por mero acaso que a vereação da vila fixava as suas férias camarárias durante o período em que se colhiam os figos e se colocavam a secar ${ }^{113}$; não era por mero acaso que os maiores cuidados desses homens, no que se refere aos campos cultivados, se dirigiam aos figueirais e à produção de figos ${ }^{114}$.

Claro que as preocupações destes homens eram motivadas pelos importantes negócios que eles próprios, e de uma maneira geral a vila, tinham oportunidade de realizar, mas até mesmo os mais pobres, quando a fortuna anda próxima, podem lucrar. E muitos jantares se fariam, entre estas famílias mais pobres, exclusiva ou prevalentemente baseados nos figos. Frescos ou secos.

Outras refeições, mesmo quentes, não exigiam utensílios de cozinha. Peixes pequenos - a sardinha em primeiro lugar porque muito abundante - podiam ser assados directamente sobre as brasas, assim como algum pedaço de carne, nomeadamente de porco, por altura da matança e até uns ovos, bem posicionados sob as cinzas da lareira e com o calor controlado podiam proporcionar uma boa refeição quente. Tudo isto acompanhado, à boa maneira medieval, com pão.

77 Talvez não sejam de todo descabidas estas considerações, se nos lembrarmos daquela família já atrás referida, em cuja habitação ficou dito que, como móvel, existia apenas uma almadraqueja velha ${ }^{115}$. Também havia em Loulé, como havia em todo o lado, a extrema pobreza.

\section{III - A MESA}

\section{A mesa e o seu lugar em casa}

78 Falar em mesa neste final da Idade Média, a não ser quando se trata de famílias abastadas, reduz-se, na maior parte das vezes, a simples figura de retórica. Porque mesa não existia ${ }^{116}$. Porém, quando este móvel fazia parte do recheio doméstico ele era, quase sempre, de $\operatorname{armar}^{117}$, o que em regra se encontra expresso de forma a não consentir dúvidas, uma vez que nos é apresentado na forma de uma mesa com os seus pés. 

mostraram ${ }^{118}$, com excepção da casa do cavaleiro Rui Lourenço, onde se encontrava uma mesa de gonzos ${ }^{19}$, móvel que, à época, era bastante raro ${ }^{120}$. Tratava-se assim, de um modo geral, de móveis que ocupavam pouco espaço - o qual, nas casas da gente comum, raramente abundava -, uma vez que, não estando em serviço, a tábua - a mesa propriamente dita - se conservava encostada a uma parede e os cavaletes em que assentava quando armada - os pés - podiam igualmente arrumar-se junto dela. 0 mesmo acontecia com aquela mesa de gonzos que, presa à parede, só ocupava espaço quando em serviço. Em casa desse mesmo cavaleiro havia, no entanto, uma outra, uma arca-mesa, móvel que, como tantos outros, na época, desempenhava mais do que uma função.

Nas habitações das famílias abastadas, chegada a hora da refeição, armada a mesa - posta a mesa no local onde se iria comer, em qualquer lugar onde se quisesse - podia colocar-se sobre ela um mantel de tecido grosso para maior conforto dos comensais ${ }^{121} \mathrm{e}$ sobre ele estendia-se uma toalha - branca - que nessas casas abastadas, e sobretudo em ocasiões especiais, podia ser bordada ou trabalhada no tear ${ }^{122}$. Aliás, a própria fonte já aqui tantas vezes citada nos informa acerca de uma toalha "lavrada", isto é, trabalhada no tear, propriedade de um cavaleiro louletano - Vasco Lourenço - que durante algum tempo se encontrou depositada na arca dos órfãos, como penhor de uma quantia em dinheiro que ele aí pedira ${ }^{123}$, a exemplo de que acontecia em diversas ocasiões e lugares.

81

Poucos em Loulé, e de acordo com a documentação em presença, usufruiriam destes requintes. Nos finais da Idade Média, a roupa era ainda um luxo dispendioso e não muitos podiam ir além do absolutamente indispensável. À luz dos inventários que chegaram até nós, só em casa de Rui Lourenço, como devia acontecer na dos outros "notáveis" da vila, a roupa de mesa abundava. Ficou registada a existência de, para lá de quatro mantéis - que nem sempre eram usados na mesa, mas tinham, vulgarmente, outras utilizações, talvez como roupa de cama -, um alquicé de mesa fino ${ }^{124}$, oito toalhas de mesa, duas das quais de linho, sem contar com as duas toalhas de lenço, de cobrir pão, a que já atrás foi feita referência ${ }^{125}$. De resto, só uma outra família tinha umas toalhas, porém, ao tempo, já velhas e rotas ${ }^{126}$.

\section{0 serviço de mesa}

Com mesa ou sem ela, os alimentos precisavam ser servidos. Em muitas casas, as mais das vezes, não seriam necessários quaisquer utensílios para o efeito e bastavam aqueles onde haviam sido cozinhados. Mas na maior parte das moradas havia alfaias próprias para colocá-los e levá-los para a mesa, quando esse móvel existia, ou, caso contrário, em qualquer outro lugar acessível a todos os comensais.

83 Para os alimentos sólidos usavam-se pratéis e talhadores grandes, isto é, o equivalente às nossas travessas ${ }^{127}$. Em Loulé tanto uns como outros se encontravam em bastantes moradias, por vezes em número considerável que, no respeitante aos pratéis podia chegar a vinte e um, embora a maioria não tivesse a função de travessa, uma vez que foi feita a distinção entre grandes e pequenos ${ }^{128}$.

84

Quando os materiais de confecção se encontram referidos eles divergem. No referente aos pratéis esse material foi sempre indicado como sendo o estanho ${ }^{129}$, mas os talhadores podiam ser de madeira ${ }^{130}$, de barro ${ }^{131}$, de barro vidrado ${ }^{132}$, de Málaga ${ }^{133}$. Quer dizer: de madeira ou de barro, embora este pudesse ser preparado de maneiras diferentes. A indiciar, talvez, que nos pratéis confeccionados com materiais mais ricos e susceptíveis de 
se riscar e deteriorar quando sobre eles se exercesse pressão com um objecto cortante, se serviria a carne ou outros alimentos já trinchados em pequenos pedaços e nos talhadores, mais robustos sob este aspecto, podiam servir-se peças inteiras. Só que, com os de Málaga, talvez houvesse que ter algum cuidado.

Esta última loiça - de Málaga - merece um pouco de atenção, até porque várias foram as peças de cerâmica que receberam aquele qualificativo. Aliás, no foral manuelino de Loulé ${ }^{134}$, como no do Silves e nos restantes algarvios que seguem este último ${ }^{135}$, parece usar-se o qualificativo "de Málaga" para designar toda a loiça de barro, vidrado, proveniente de importação, mais onerada pelo tributo do que a mesma loiça, vidrada ou não, fabricada no reino.

Era este um tipo de baixela que pelo prestígio adquirido se podia encontrar em qualquer lado ${ }^{136}$, inclusive nos grandes enxovais como o da Infanta D. Beatriz, inventariado em 1507 e onde ficaram declarados treze pratéis de "malegua de Valença" ${ }^{137}$. Mas aqui, em Loulé, tal loiça parece ter sido recorrente, uma vez que ficou registada em diversas habitações e representada por vários utensílios, como adiante voltarei a referir.

Documenta-se, assim, um fluxo comercial de alguma importância, por certo a privilegiar as rotas que ligavam o Sul peninsular. Tratava-se de uma loiça vidrada, dourada, profusamente decorada, proveniente dos chamados barros de Sevilha e Málaga e em que se tinham por assim dizer especializado as olarias sevilhanas e valencianas. Era conhecida como labor e obra de Málaga ${ }^{138}$.

Fabricados com materiais mais ou menos ricos, de acordo com as posses de quem os adquiria e também com o uso a que se destinavam, com formas mais ou menos requintadas ${ }^{139}$, pratéis e talhadores existiam em muitas casas louletanas.

Outros alimentos, sobretudo semi-líquidos, vinham à mesa em bacias ${ }^{140}$ de cerâmica ou de metal $^{141}$, em tigelas grandes ${ }^{142}$, em altamias, também uma espécie de taças ${ }^{143}$. Talvez menos fáceis de encontrar em outras regiões, estas últimas ${ }^{144}$, eram aqui, em Loulé, uma alfaia, se não recorrente também não escassa, uma vez que existia em diversas moradas e presente, sempre, por intermédio de várias unidades, que podiam ser até $\operatorname{cinco}^{145}$, neste caso todas de Málaga ${ }^{146}$, como, aliás, também as tigelas. A bebida servia-se em pichéis, uma espécie de jarras, que também podiam ser de Málaga ${ }^{147}$.

90 É possível que algumas das jarras mencionadas nos inventários e a que atrás foi feita referência, também servissem à mesa ${ }^{148} \mathrm{e}$ talvez fosse essa igualmente a função da única albarrada - também uma espécie de jarra - constante nos espólios aqui em análise ${ }^{149}$, até porque esta alfaia podia, em alguns casos, receber uma tampa ${ }^{150}$, a fim de resguardar de impurezas o seu conteúdo.

91 utros artefactos de serviço à mesa eram aqui muito raros: apenas dois saleiros, ambos de estanho $^{151}$ - é sabido que, na Idade Média, vinham à mesa para cada comensal salgar os alimentos como preferia -, uma salsinha, isto é, uma molheira, igualmente de estanho ${ }^{152}$ e, como requinte máximo, um pratel grande, de água às mãos ${ }^{153}$.

92 Por último, como utensílios de uso colectivo, mas que, penso, poderiam ser utilizados em diversas outras circunstâncias e em diversas outras funções, alguns prateiros ${ }^{154}$ e um charão, qualificado, este, de Évora ${ }^{155}$, peças, umas e outra, de significado não perfeitamente claro, mas que podiam ser tabuleiros ${ }^{156}$. 


\section{Que loiça individual?}

93 Loiça individual era muito pouca. Em primeiro lugar as escudelas ${ }^{157}$ ou cuncas ${ }^{158}$, a que actualmente chamaríamos tigelas ou malgas e que os convivas usavam para os alimentos líquidos e semi-líquidos. De uma maneira geral, eram confeccionados em madeira - e é nessa qualidade que o foral manuelino de Loulé no-las apresenta ${ }^{159}-$, se bem que existiam algumas em cerâmica. Foram, porém, declaradas em poucas casas, talvez mais pelo seu diminuto valor comercial, ao menos as de pau, do que pela sua inexistência, o que igualmente tem sido considerado em outros locais. $\mathrm{O}$ facto de, em Loulé, elas não se encontrarem declaradas nas casas mais ricas é bastante sintomático.

Onde nos foram dadas a conhecer, as escudelas podiam ser grandes ou pequenas, o que sugere, para as maiores, um uso partilhado ou até colectivo, conforme o tamanho; as cuncas, apenas inventariadas, com este nome, em um dos espólios, foram ditas pequenas, em número de três, mas acrescentaram-se outras três, designadas por cunquinhas, o que nos remete para um tamanho ainda mais pequeno, a sugerir a sua utilização, não para os habituais caldos ou papas, alimentos a que normalmente serviam, mas para a bebida. A ser assim, a escudela - ou cunca - individual, a que diversos investigadores se têm referido, seria na época, em Loulé, muito pouco comum.

Partilhado era também o talhador pequeno, que servia, em regra, para dois comensais sentados lado a lado ${ }^{160}$, mas que podia servir a quatro, se sentados a uma mesa muito estreita.

Copos e púcaros eram muito raros. É certo que os púcaros, ditos para beber água, constavam entre as peças de olaria na tabela estabelecida pela câmara municipal e já atrás por diversas vezes referida ${ }^{161}$, mas nenhum ficou declarado nos inventários que chegaram até nós; quanto aos copos, apenas um nos foi dado a conhecer ${ }^{162}$, talvez porque confeccionado em estanho, um material caro e portanto de certo prestígio.

Talheres pode dizer-se que não havia, na Idade Média. Colheres eram raras e mais raramente ainda constavam dos inventários, e de uma maneira geral eram de pau, o que impede ou, pelo menos, muito dificulta a sua recuperação pelos arqueólogos. Quando a documentação escrita as refere são, as mais das vezes, de cozinha. Todavia, em determinados lugares e em condições especiais de humidade do solo, elas puderam ser encontradas, como já atrás ficou lembrado. Nesses casos, as colheres mais pequenas do que as de cozinha apresentam-se com cabos curtos, correspondentes à largura da palma da mão a indicar uma manutenção sólida do utensílio, firmemente sustido pela mão fechada sobre o cabo ${ }^{163}$.

É possível que existissem colheres destas em Loulé, embora negligenciadas pelos escrivães dos inventários, mas na maioria dos casos elas eram dispensáveis. Existiam, isso sim, algumas colheres de prata, nas casas mais abastadas, mas essas eram, além de raras, de uso muito esporádico e ciosamente guardadas, como quaisquer outros objectos de prata, pelo valor intrínseco que possuíam e dos quais os seus donos se serviam, em caso de necessidade e falta de liquidez. Haja em vista o caso do já tantas vezes citado Rui Lourenço, que à sua morte possuía alguns objectos de prata - entre os quais quatro colheres -, todos empenhados a troco de quantias várias ${ }^{164}$.

Garfos como os que conhecemos e utilizamos hoje em dia não existiam. É certo que em Itália se pode ter conhecido precocemente o garfo pequeno, de mesa. Mas esse era um 
objecto muito raro e munido apenas de dois dentes muito separados entre $\mathrm{si}^{165}$, o que significa serem destinados apenas a espetar os alimentos sólidos e a depositá-los no talhador. Função que era, de preferência, desempenhada pela faca, até porque esta também cortava os alimentos quando eles não haviam sido previamente trinchados $\mathrm{e}$ continuava a fazer o mesmo trabalho no talhador que o comensal tinha à sua frente, ou sobre a fatia de pão em que ele o depositara.

Por sua vez, as facas de mesa eram também muito raras e, como a generalidade dos investigadores tem comprovado, eram todas de lâmina pontiaguda, destinadas a espetar ${ }^{166}$. Não obstante a sua raridade - não só nos inventários como também na arqueologia e na iconografia, onde uma ou duas facas parecem suficientes para toda uma mesa -, elas tinham que ser muito importantes no decorrer de qualquer refeição para cortar todos os alimentos sólidos e desde logo para o pão que, como mais uma vez a iconografia mostra, vinha inteiro para a mesa. E eram para ele, sobretudo, que essas poucas facas aí se encontravam. No entanto cada comensal precisava utilizar com insistência um instrumento cortante ao logo de toda a refeição.

101 A faca era, assim, um utensílio individual que cada conviva trazia consigo ${ }^{167}$ e podia ser também qualquer outro instrumento cortante e de ponta afiada. De resto, era a mão que se usava à mesa para quase tudo. Num hábito transversal a toda a sociedade e que se prolongou ainda para cá da Idade Média.

\section{0 consumo da refeição}

Com uma tão diminuta baixela de serviço à mesa, as formas de comportamento dos comensais tinham que ser muito rudimentares e tanto mais que, em casa, essa baixela escasseava.

Entre as famílias mais desmunidas, com poucas alfaias e sem mesa para apoiar as existentes, a refeição só podia decorrer de um modo muito simples ${ }^{168}$. Se o jantar, a refeição de antes do meio-dia e a mais importante, nem sempre podia ser tomada em casa porque o trabalho decorria longe, pelo menos, a ceia, a refeição da noite, era tomada ao canto da lareira, à volta do lume, muitas vezes a única fonte de claridade e, no Inverno, o lugar mais quente e aconchegado da casa. Os alimentos líquidos e semilíquidos eram servidos em escudelas ou cuncas, individuais ou, possivelmente as mais das vezes, partilhadas, que se levavam directamente à boca. Para facilitar o acto algumas delas tinham asas ou orelhas ${ }^{169}$. Os alimentos sólidos que restavam na escudela ou que, por vezes, eram cozinhados à parte, colhiam-se com os dedos para uma fatia de pão e assim eram consumidos.

104 A bebida, entre nós como em toda a região mediterrânica e para todas as idades, o vinho, tomava-se directamente do pichel ou da jarra que circulava entre todos os comensais e do qual cada um bebia, à sua vez ${ }^{170}$.

105 Entre as famílias um pouco mais acomodadas, com mesa ou sem ela, a refeição continuava, as mais das vezes, a ser servida no local da confecção, isto é, à volta da lareira. Se em casa havia uma mesa sobre ela se colocava o pão e talvez um talhador com alimentos sólidos. Um e outros eram cortados com uma faca e transferidos para talhadores pequenos, cada um dos quais seria partilhado por dois ou mais membros da família. Ou simplesmente colocados sobre as fatias de pão. A bebida podia continuar a ser 
tomada directamente do pichel, ou haver em casa um copo, ou um púcaro ${ }^{171}$, que circulava entre todos.

Compreende-se assim que as boas maneiras à mesa recomendassem que, antes de beber, se limpasse a boca, e quando a bebida se servia em copo cada um bebesse todo o conteúdo que lhe era apresentado, sem deixar restos para quem, em seguida, se servisse ${ }^{172}$.

À medida que se subia na escala social e económica o serviço de mesa ia-se complexificando. 0 próprio lugar da refeição podia deixar de ser a cozinha.

Foi visto atrás que algumas famílias louletanas declararam possuir uma mesa de armar, que se deslocava para qualquer lugar da casa, a mudar o lugar do repasto sempre que se queria. Só na morada do cavaleiro Rui Lourenço - e por certo nas de outros da sua igualha - haveria um lugar fixo para o efeito, porque a sua mesa de gonzos, embora também de armar, estava presa à parede. Mas ele tinha alem disso, como atrás ficou dito, uma arcamesa $^{173}$, o que de qualquer modo lhe permitia mudar o lugar da refeição, embora talvez com um pouco mais de dificuldade.

109 Sobre a mesa podia colocar-se um mantel e sobre ele uma toalha. Já foi visto que as toalhas, embora raras em Loulé, existiam nas moradias mais ricas. Sobre a toalha colocavam-se, para além dos já mencionados pichéis, jarras, talhadores, taças, também saleiros e salsinhas, ou salseirinhas - molheiras, como hoje diríamos. Nas casas de maior proeminência uns e outras representados por diversos exemplares, porque cada comensal podia salgar a comida a seu gosto e escolher o molho que preferisse, no caso, claro, de haver mais do que um só.

110 Estando o pão inteiro na mesa e havendo poucas facas de serviço, como já foi sublinhado, os convivas podiam servir-se cortando uma fatia com a sua faca de uso pessoal. Mas com ela também cortavam a carne e o peixe. Por isso os tratados medievais de boas maneiras à mesa recomendavam que a faca estivesse sempre bem limpa ${ }^{174}$.

111 Se os pedaços cortados da travessa e retirados com a mão eram imergidos nos molhos e colocados no talhador onde podia estar já uma fatia de pão que o molho tornava mais saborosa ${ }^{175}$, também a mão do comensal ficava mais suja, e cada vez mais, porque sempre em contacto estreito com a comida. Por isso, tanto a faca como as mãos precisavam limpar-se várias vezes. Para o efeito havia nestas casas mais ricas - apenas em casa de Rui Lourenço, neste acervo documental em que me apoio ${ }^{176}$ - tiras de pano que se prendiam à toalha, as chamadas longeiras ou napeiras, uma espécie de guardanapos colectivos, onde se iam limpando facas e mãos.

112 Porém, logo no início da refeição era preciso que todos verificassem que essas mãos que iriam manter um tão estreito contacto com a comida a ingerir por todos estavam limpas. Deviam, pois, lavar-se antes e depois de comer, operação que devia ser ostensivamente pública para poder ser comprovada por todos. Assim, nas casas de mais aparato a aç̧ão processava-se já à mesa, com todos presentes. Daí a expressão "água às mãos" com que se qualificavam algumas das alfaias de serviço que em regra eram duas: um pichel ou um gomil, dois tipos de jarra que para o efeito parecem equivaler-se ${ }^{177}$ e uma bacia ou pratel, por certo mais fundo que os de serviço à mesa. A água era lançada do pichel ou gomil, por um servidor, sobre as mãos dos convivas, caindo no bacio ou pratel, sustido por outro servidor ${ }^{178}$.

113 Em Loulé este aparato devia ser raro. Como já ficou dito, só na casa de maior riqueza que os inventários nos mostraram foi arrolada uma alfaia de "água às mãos", no caso um pratel ${ }^{179}$. A ser assim, o processo seguido tinha, por força, que ser diferente do usado nas 
moradias de maior aparato e cada um dos comensais lavaria as mãos na água contida no pratel. A não ser que a outra alfaia da dupla - o gomil ou o pichel - tivesse ficado esquecido ou escamoteado ou fosse substituído por qualquer jarra usada também para outras funções.

Mais algumas famílias havia, sem dúvida, em Loulé, entre as elites da vila, onde o aparato de mesa passava por requintes semelhantes ou até mais elaborados - águas perfumadas, por exemplo ${ }^{180}$ - se não sempre, ao menos em ocasiões especiais.

\section{IV - PALAVRAS FINAIS}

115 Embora uma documentação pouco abundante, ela coloca-nos em presença de famílias pertencentes, como atrás ficou dito, aos vários escalões sociais e económicos que existiam em todas as sociedades da época, a abranger toda ou quase toda a população louletana de Quatrocentos.

Em regra, eram famílias possuidoras de uma baixela pobre e pouco abundante, ainda mesmo sabendo, como também atrás ficou lembrado, que nem todos os artefactos existentes em casa ficaram registados. Mesmo considerando esse aspecto percebem-se muitas faltas de objectos básicos, indispensáveis ao normal funcionamento do trabalho doméstico respeitante à confecção e consumo das refeições, ainda que muito simples. Todavia, tem-se verificado, um pouco por todo o lado, que raras habitações na época eram autónomas nesta como em outras vertentes do viver quotidiano e sabe-se que as faltas eram, as mais das vezes, colmatadas por pedidos de empréstimo entre vizinhas ${ }^{181}$.

Não admira que assim acontecesse em Loulé, ainda mesmo que a documentação nos cale, como tantas outras, esta faceta do quotidiano de antanho.

\section{BIBLIOGRAFIA}

Fontes impressas

Actas de vereação de Loulé. Séculos XIV-XV, supl. de Al'-Ulyā, n.ำ 7. Loulé: Arquivo Histórico

Municipal de Loulé - Câmara Municipal de Loulé, 1999-2000.

Forais manuelinos do reino de Portugal e do Algarve conforme o exemplar do Arquivo Nacional da Torre do Tombo de Lisboa. Ed. Luiz Fernando de Carvalho Dias. Vol. 3 - Entre Tejo e Odiana. Lisboa: Edição do Autor, 1965.

Fundo dos Órfãos de Loulé. Séculos XV e XVI. Ed. Maria de Fátima Machado. Loulé: Câmara Municipal de Loulé - Arquivo Municipal, 2016.

O "Livro de Cozinha" da infanta D. Maria de Portugal. Ed. Salvador Dias Arnaut e Giacinto Manuppella. Coimbra: Universidade de Coimbra, 1967.

LOPES, Fernão - Crónica de D. João I. Prefaciada por António Sérgio e preparada por M. Lopes de Almeida e A. de Magalhães Basto, vol. I e II. Porto: Livraria Civilização, 1945-1949. 
Ordenações Afonsinas. Nota de apresentação por Mário Júlio de Almeida Costa, nota textológica por Eduardo Borges Nunes, livro IV. Lisboa: Fundação Calouste Gulbenkian, 1984.

“Transcrição do foral de Loulé”, por Luís Filipe Oliveira, Maria de Fátima Botão e Teresa Rebelo da Silva. In SERRA, Manuel Pedro (Coord.) - O foral de Loulé 1504 - D. Manuel. Loulé: Câmara Municipal de Loulé, 2004, pp. 65-117.

Estudos

ABELLÁN PÉREZ, Juan - El ajuar de las viviendas jerezanas en época de Isabel I de Castilla (1474-1504). Cadiz: Servicio de Publicaciones de la Universidad de Cadiz, 2011.

ABELLÁN PÉREZ, Juan - El ajuar de las viviendas murcianas a fines de la Edad Media (cultura material a traves de los textos). Múrcia: Real Academoa Alfonso X El Sabio, 2009.

ALEXANDRE-BIDON, Danièle - "Dans les cuisines du Moyen Âge". Dans les cuisines du Moyen Âge: manières de faire, Histoire médiévale, hors serie, n. 8, Nov. 2004-Jan. 2005, pp. 42-47.

ALEXANDRE-BIDON, Danièle; BECK BOSSARD, Corinne - "La préparation des repas et leur consommation en Forez au XV $\mathrm{X}^{\mathrm{e}}$ siècle d'après les sources archéologiques". in Manger et boire au Moyen Âge. Actes du Colloque de Nice (15-17 octobre 1982). Tome 2 - Cuisine, manières de table, régimes alimentaires. Nice: Centre d'Études medievales de Nice, 1984, pp. 58-71.

ARNAUT, Salvador Dias - “A arte de comer em Portugal na Idade Média”, Introdução histórica a 0 "Livro de Cozinha" da infanta D. Maria de Portugal. Ed. Salvador Dias Arnaut e Giacinto Manuppella. Coimbra: Universidade de Coimbra, 1967, pp. XXIII-CXXX.

ARRIVÉ, Nadège - "Le vin en France au XVI ${ }^{\mathrm{e}}$ siècle. Aspects du vin: productions, usages et pratiques culinaires". in VIALLON-SCHONEVELD, Marie (Ed.) - Le boire et le manger au XVI e siècle. Actes du XI ${ }^{e}$ colloque du Puy-en-Valay. Saint-Étienne: Publications de l'Université de Saint-Étienne, 2004, pp. 173-194.

BARROS, Maria Filomena Lopes de - Tempos e espaços de mouros: a minoria muçulmana no reino português (séculos XII a XV). Lisboa: Fundação Calouste Gulbenkian - FCT, 2007.

BEIRANTE, Maria Ângela - "Ritos alimentares em algumas confrarias portuguesas medievais". in Territórios do sagrado: crenças e comportamentos na Idade Média em Portugal. Lisboa: Colibri, 2011, pp. 185-197.

BECK-BOSSARD, Corinne, v. ALEXANDRE-BIDON, Danièle.

BOTÃo, Maria de Fátima - A construção de uma identidade urbana no Algarve medieval: o caso de Loulé. Casal de Cambra: Caleidoscópio, 2009.

BOTÃO, Maria de Fátima - "Os eixos estruturantes de uma história”. in SERRA, Manuel Pedro (Coord.) - O foral de Loulé 1504 - D. Manuel. Loulé: Câmara Municipal de Loulé, 2004, pp. 15-34.

BOTÃo, Maria de Fátima - Silves, a capital de um reino medievo. Silves: Câmara Municipal de Silves, 1992.

BRESC, Henri, v. BRESC-BAUTIER, Geneviéve.

BRESC-BAUTIER, Geneviève; BRESC, Henri; HERBETH, Pascal - "L'équipement de la cuisine et la table en Provence et en Sicile (XIV $-\mathrm{XV}^{\mathrm{e}}$ siècles). Étude comparée”. in Manger et boire au Moyen Âge . Actes du Colloque de Nice (15-17 octobre 1982). Tome 2 - Cuisine, manières de table, régimes alimentaires. Nice: Centre d'Études medievales de Nice, 1984, pp. 45-58.

CARDOSO, João Luís; FERNANDES, Isabel Cristina F. - “A economia alimentar de Muçulmanos e Cristãos do castelo de Palmela: um contributo”. Arqueologia medieval 12 (2012), pp. 211-233. 
- v. FERNANDES, Isabel Cristina.

- v. GOMES, Mário Varela.

CARVALHO, A. Rafael, v. FERNANDES, Isabel Cristina.

CATARINO, Helena - O Algarve oriental durante a ocupação islâmica: povoamento rural e recintos fortificados. Al'-Ulyā 6, vols. I e II (1997-1998).

CATARINO, Helena - “O castelo de Salir: resultados da exploração dos silos”. Al'-Ulyā 4 (1995), pp. 9-30.

CATARINO, Helena - Cerâmicas islâmicas do castelo de Salir. Loulé: Museu Municipal de Arqueologia, 1992.

CATARINO, Maria Manuela - Na margem direita do Baixo Tejo. Paisagem rural e recursos alimentares (sécs. XIV-XV). Cascais: Patrimonia, 2000.

CAVACO, Sandra, v. COVANEIRO, Jaquelina.

CICLAIRE, Philippe - Les cuissons alimentaires au Moyen Âge. Paris: L'Harmattan, 2017.

COELHO, Maria Helena da Cruz - "Apontamentos sobre a comida e a bebida do campesinato coimbrão em tempos medievais". in Homens, espaços e poderes (séculos XI-XVI). Vol. I - Notas do viver social. Lisboa: Livros Horizonte, 1990, pp. 9-22.

COELHO, Maria Helena da Cruz - "O senhorio crúzio de Alvorge na centúria de Trezentos". in Homens, espaços e poderes (séculos XI-XVI). Vol. II - Domínio senhorial. Lisboa : Livros Horizonte, 1990, pp. 31-92.

COLLINA-GIRARD, Jacques - Le feu avant les allumettes. Expérimentation et mythes téchniques. Paris : Éditions de la Maison des sciences de l'homme, 1998.

CONTAMINE, Philippe - La vie quotidienne pendant la guerre de Cent Ans. France et Angleterre (XIV ${ }^{e}$ siècle). [Paris]: Hachette, 1976.

CORRIENTE, Federico - Diccionario de arabismos y voces afines en iberoromance. Madrid: Gredos, 1999.

COULET, Noël - “L'équipement de la cuisine à Aix-en-Provence au XV siècle". Annales du Midi 103 (Jan. 1991), pp. 5-17.

COULET, Noël - "Pour une histoire du jardin. Vergers et potagers à Aix-en-Provence: 1350-1450". Le Moyen Âge 73 (1967), pp. 239-270.

COVANEIRO, Jaquelina; CAVACO, Sandra; LOPES, Gonçalo - "Importações cerâmicas de Tavira na Baixa Idade Média". Arqueologia Medieval 11 (2010), pp. 113-120.

DETRY, Cleia, v. FERNANDES, Isabel Cristina.

DIETRICH, Anne - "Les petits métiers du bois et les arts de la table à la fin du Moyen Âge". in DIETRICH, Anne; RAVOIRE, Fabienne (Ed.) - La cuisine et la table dans la France de la fin du Moyen Âge: contenus et contenants du XIV ${ }^{e}$ au XVI siècle. Turnhout: Brepols, 2009, pp. 157-165.

DUARTE, Luís Miguel - "Eleições municipais no Algarve no início do século XV”. in Actas das I Jornadas de história medieval do Algarve e Andaluzia. Loulé: Câmara Municipal de Loulé, 1987, pp. 297-304.

DUARTE, Luís Miguel - "Quinhentos anos depois". in SERRA, Manuel Pedro (Coord.) - O foral de Loulé 1504 - D. Manuel. Loulé: Câmara Municipal de Loulé, 2004, pp. 9-11. 
FERNANDES, Isabel Cristina Ferreira; CARDOSO, João Luís; DETRY, Cleia - “Cozinhar e comer no castelo medieval de Palmela”. in GÓMEZ MARTÍNEZ, Susana (Ed.) - Memória dos sabores do Mediterrâneo. Mértola: Campo Arqueológico / Centro de Estudos Arqueológicos das Universidades de Coimbra e Porto, 2012, pp. 113-127.

FERNANDES, Isabel Cristina Ferreira; CARVALHO, A. Rafael - "Abordagem arqueológica da Palmela medieval cristã”. Arqueologia medieval 5 (1997), pp. 225-241.

FERREIRA, Maria Elvira; SARAIVA, Isabel - "Plantas da flora local com valor alimentar e aromático". in VALAGÃO, Maria Manuel (Org.) - Tradição e inovação alimentar: dos recursos silvestres aos itinerários turísticos. Lisboa: Colibri - INIAP, 2006, pp. 21-43.

FERREIRA, Maria Valentina Garcia - “A fruta de Loulé na Europa medieval: análise de um manuscrito do século XV”. Al'-Ulyā 9 (2003), pp. 215-239.

FRAMOND, Martin de - “À la table d'un marchand bourgeois du Puy”. in VIALLON-SCHONEVELD, Marie (Ed.) - Le boire et le manger au XVI siècle. Actes du XI colloque du Puy-en-Valay. Saint-Étienne: Publications de l'Université de Saint-Étienne, 2004, pp. 103-150.

GÁZQUEZ ORTIZ, Antonio - La cocina en tiempos del arcipreste de Hita. Madrid: Alianza Editorial, 2002.

GOMES, Mário Varela; GOMES, Rosa Varela; CARDOSO, João Luís - “Aspectos do quotidiano numa casa de Silves durante o século XV". Silves nos Descobrimentos. Xelb: revista de arqueologia, etnologia e história 3 (1996), pp. 33-78.

GOMES, Rosa Varela, v. GOMES, Mário Varela.

GONÇALVES, Iria - “A alimentação”. In MATTOSO, José (dir.) - História da vida privada em Portugal. Vol. I - A Idade Média. Coord. Bernardo Vasconcelos e Sousa. Lisboa: Temas e Debates, 2010, pp. 226-259.

GONÇALVES, Iria - “Alimentação medieval: conceitos, recursos, práticas”. in Actas dos VI Cursos internacionais de Verão de Cascais (5 a 10 de Julho de 1999). Vol. 2, A alimentação. Cascais: Câmara Municipal de Cascais, 2000, pp. 29-48.

GONÇALVES, Iria - “A colheita régia medieval, padrão alimentar de qualidade (um contributo beirão)". Revista da Faculdade de Ciências Sociais e Humanas 6 (1992-1993), pp. 175-189.

GONÇALVES, Iria - "Dant vitam maiordomo de quali habuerint. Apontamentos sobre um direito senhorial à luz dos inquéritos afonsinos”. in Por terras de Entre-Douro-e-Minho com as inquirições de Afonso III. Porto: CITCEM - Edições Afrontamento, 2012, pp. 149-177.

GONÇALVES, Iria - À mesa nas terras de Alcobaça em finais da Idade Média. Alcobaça: DGPC/Mosteiro de Alcobaça, 2017.

GONÇALVES, Iria - “A propósito do pão da cidade na Baixa Idade Média portuguesa”. in SILVA, Carlos Guardado da (Ed.) - Turres Veteras IX. História da Alimentação. Torres Vedras: Câmara Municipal de Torres Vedras - Ed. Colibri, 2007, pp. 49-72.

HERBETH, Pascal - "Les utensiles de cuisine en Provence médiévale (XIII ${ }^{\mathrm{e}}-\mathrm{XV}$ e siècle)”. Médiévales 5 (1983), pp. 89-94.

- v. BRESC-BAUTIER, Geneviéve.

LATREMOLIÉRE, Élisabeth - "Cuisines et tables royales: les objects témoignent". in COCULA, Annie; COMBET, Michel (Ed.) - Chateaux, cuisines et dépendances. Bordéus: Ausonius, 2014, pp. 219-232.

LAURIOUX, Bruno - A Idade Média à mesa. Mem Martins: Publicações Europa-América, 1992. 
LE ROY LADURIE, Emmanuel - Montaillou, village occitan de 1294 a 1324. Paris: Gallimard, 1975.

LOPES, Gonçalo, v. COVANEIRO, Jaquelina.

LUZIA, Isabel - “O espólio cerâmico da cerca do convento”. Al'-Ulyā 5 (1996), pp. 51-73.

MACHADO, Maria de Fátima - "Os órfãos de Loulé”. in Fundo dos órfãos de Loulé. Séculos XV e XVI. Ed. Maria de Fátima Machado. Loulé: Câmara Municipal de Loulé - Arquivo Municipal, 2016, pp. 5-15.

MACHADO, Maria de Fátima - “Os órfãos de Loulé e a gestão do seu património nos séculos XV e XVI”. Al'-Ulyā 18 (2017), pp. 42-65.

MACIAS, Santiago - Mértola islâmica. Estudo histórico-arqueológico do bairro da Alcáçova (séculos XIIXIII). Mértola: Campo Arqueológico de Mértola, 1996.

MACIAS, Santiago - Mértola, o último porto do Mediterrâneo. Vol. I. Mértola: Campo Arqueológico de Mértola, 2005.

- v. TORRES, Cláudio.

MALTEZ, Maria Teresa Nesbitt Rebelo da Silva - Os recursos alimentares no Algarve oriental (século XIV). Lisboa: Faculdade de Ciências Sociais e Humanas, Universidade Nova de Lisboa, 1993. Dissertação de Mestrado.

MARQUES, A. H. de Oliveira - "Para a história do concelho de Loulé na Idade Média". in Actas das III Jornadas de história medieval do Algarve e Andaluzia. Loulé: Câmara Municipal de Loulé, 1989, pp. $17-23$.

MARQUES, A. H. de Oliveira - Introdução à história da agricultura em Portugal. A questão cerealífera durante a Idade Média. 3. ed. ed., Lisboa: Edições Cosmos, 1978.

MARQUES, A. H. de Oliveira - A sociedade medieval portuguesa. Aspectos de vida quotidiana. 6. ${ }^{\mathrm{a}}$ ed., Lisboa: Esfera dos Livros, 2010.

MARTINS, Luísa Fernanda Guerreiro - Contributos para a história da alimentação algarvia a partir das actas de vereação do concelho de Loulé (1384-1488). Faro: Direção Regional de Cultura do Algarve, 2016.

MAZZI Maria Serena; RAVEGGI, Sergio - Gli uomini e le cose nelle campagne fiorentine del Quattrocento . Florença: Casa Editrice Leo S. Olschki, 1983.

NADA PATRONE, Anna Maria - Il cibo del ricco ed el cibo del povero. Contributo alla storia qualitativa dell' alimentazione. L'Arga Pedemontana negli ultimi secoli del Medio Evo. Turim: Centro Studi Piemontesi, 1989.

PALMA, Manuel Passinhas da, v. TORRES, Cláudio.

PIPONNIER, Françoise - "Do lume à mesa: arqueologia do equipamento alimentar no fim da Idade Média”. in FLANDRIN, Jean-Louis; MONTANARI, Massimo (dir.) - História da alimentação. Vol. 2, Da Idade Média aos tempos actuais. Lisboa: Terramar, 2001, pp. 123-132.

RAVEGGI, Sergio, v. MAZZI, Maria Serena.

REDON, Odile - "Espace, objects et gestes de la cuisine dans la Toscane siennoise et Florentine des XIV $-X V^{\mathrm{e}}$ siècles”. Médiévales 12 (1987), pp. 101-110.

REGO, Miguel, v. TORRES, Cláudio.

ROSSELLÓ BORDOY, Guillermo - El ajuar de las casas andalusíes. Málaga: Editorial Sarriá, 2002. 
SANTOS, Maria José Azevedo - Jantar e cear na corte de D. João III. Leitura, transcrição e estudo de dois livros de cozinha do rei (1524-1542). Vila do Conde - Coimbra: Câmara Municipal de Vila do Conde/ Centro de História da Sociedade e da Cultura, 2002.

SANTOS, Maria José Azevedo - "O peixe e a fruta na alimentação da corte de D. Afonso V: Breves notas”. in A alimentação em Portugal na Idade Média. Fontes, Cultura, Sociedade. Coimbra: Inatel, 1997, pp. 1-33.

SARAIVA, Isabel, v. FERREIRA, Maria Elvira.

SILVA, Joana Gomes da, v. VALAGÃo, Maria Manuel.

STOUFF, Louis - Ravitaillement et alimentation en Provence aux XIV et XVe siècles. Paris - La Haye: De Gruyter Mouton, 1970.

STOUFF, Louis - La table provençale. Boire et manger en Provence à la fin du Moyen Âge. Avinhão: Editions A. Barthélemy, 1996.

TORRES, Cláudio; PALMA, Manuel Passinhas da; REGO, Miguel; MACIAS, Santiago - “Técnicas e utensílios de conservação dos alimentos na Mértola islâmica”. Arqueologia Medieval 4 (1996), pp. 203-217.

VALAGÃO, Maria Manuel - "Cozinha mediterrânica no Alentejo - intemporalidade das práticas". in GÓMEZ MARTÍNEZ, Susana (Ed.) - Memória dos sabores do Mediterrâneo. Mértola: Campo Arqueológico / Centro de Estudos Arqueológicos das Universidades de Coimbra e Porto, 2012, pp. 225-234.

VALAGÃO, Maria Manuel - ; SILVA, Joana Gomes da - “As tradições alimentares”. in VALAGÃO, Maria Manuel (Org.) - Tradição e inovação alimentar: dos recursos silvestres aos itinerários turísticos. Lisboa: Colibri - INIAP, 2006, pp. 81-152.

VARELA SIEIRO, Xaime - Léxico cotián na Alta Idade Media de Galicia: o enxoval. A Coruña: Ediciós do Castro, 2003.

VITERBO, Joaquim de Santa Rosa de - Elucidário das palavras, termos e frases que em Portugal antigamente se usaram e que hoje regularmente se ignoram. Ed. crítica de Mário Fiúza, 2 vols. Porto: Civilização, 1966.

WOLFF, Philippe - "Inventaires villageois du Toulousain (XIV -XVe siècle)". Bulletin Philologique et Historique 2 (1968), pp. 481-544.

\section{NOTAS}

1. Essa documentação foi recentemente publicada sob o título Fundo dos Órfãos de Loulé. Séculos XV e XVI. Ed. Maria de Fátima Machado. Loulé: Câmara Municipal de Loulé / Arquivo Municipal, 2016.

2. Fundo dos Órfãos de Loulé, pp. 19-26.

3. Fundo dos Órfãos de Loulé, pp. 106-110.

4. Fundo dos Órfãos de Loulé, p. 100.

5. Fundo dos Órfãos de Loulé, p. 106.

6. Actas de vereação de Loulé. Séculos XIV-XV, sep. de Al'-Ulyā, n.ำ 7. Loulé: Arquivo Histórico Municipal de Loulé - Câmara Municipal de Loulé, 1998-2000, pp. 202, 203, 251. A p. 203 é dito fidalgo.

7. Fundo dos Órfãos de Loulé, p. 91.

8. Vejam-se MARQUES, A. H. de Oliveira - "Para a história do concelho de Loulé na Idade Média". in Actas das III Jornadas de história medieval do Algarve e Andaluzia. Loulé: Câmara Municipal de 
Loulé, 1998, pp. 17-23; BOTÃO, Maria de Fátima - A construção de uma identidade urbana no Algarve medieval: o caso de Loulé. Casal de Cambra: Caleidoscópio, 2009, pp. 202-207.

9. Veja-se acima a nota 6.

10. MACHADO, Maria de Fátima - "Os órfãos de Loulé e a gestão do seu património nos séculos XV e XVI”. Al'-Ulyā 18 (2017), p. 53.

11. Fundo dos Órfãos de Loulé, pp. 106-110. Adiante irei referindo algumas das peças únicas ou raras neste acervo documental, que haviam pertencido à casa daquele cavaleiro.

12. Fundo dos Órfãos de Loulé, pp. 30, 35, 45, 53, 112.

13. Fundo dos Órfãos de Loulé, p. 112.

14. Maria Serena MAZZI e Sergio RAVEGGI (Gli uomini e le cose nelle campagne fiorentine del Quattrocento. Florença: Casa Editrice Leo S. Olschki, 1983, p. 216) encontraram também alguns daqueles que, ao menos aparentemente, não tinham qualquer utensílio e haviam de comer na mais absoluta pobreza. Famílias que tinham que renunciar até ao mais essencial, tal como acontece, lembram os autores, com S. Francisco de Assis, de acordo com o seu biógrafo.

15. Podem ver-se, por exemplo: WOLFF, Philippe - "Inventaires villageois du Toulousain (XIV ${ }^{e_{-}}$ XVe siècle)". Bulletin Philologique et Historique 2 (1968), p. 481; HERBETH, Pascal - "Les utensiles de cuisine en Provence médiévale (XIII ${ }^{\mathrm{e}}-\mathrm{XV}^{\mathrm{e}}$ siècle)". Médiévales 5 (1983), p. 91; BRESC-BAUTIER Geneviève ; BRESC, Henri ; HERBETH Pascal - "L'équipement de la cuisine et la table en Provence et en Sicile (XIV $-\mathrm{XV}^{\mathrm{e}}$ siècles). Étude comparée". in Manger et boire au Moyen Âge. Actes du Colloque de Nice (15-17 octobre 1982). Tome 2 - Cuisine, manières de table, régimes alimentaires. Nice: Centre d'Études medievales de Nice, 1984, pp. 52, 55; FRAMOND Martin de - "À la table d'un marchand bourgeois du Puy". in VIALLON-SCHONEVELD, Marie (Ed.) - Le boire et le manger au XVI ${ }^{e}$ siècle. Actes $d u X^{e}$ colloque du Puy-en-Valay. Saint-Étienne: Publications de l'Université de Saint-Étienne, 2004, p. 111; ABELLÁN PÉREZ, Juan - El ajuar de las viviendas murcianas a fines de la Edad Media (cultura material à traves de los textos). Múrcia: Real Academia Alfonso X El Sabio, 2009, pp. 62-63; ABELLÁN PÉREZ, Juan - El ajuar de las viviendas jerezanas en época de Isabel I de Castilla (1474-1504). Cadiz: Servicio de Publicaciones de la Universidad de Cadiz, 2011, p. 70.

16. Também nestas listas que me proponho trabalhar, as colheres primam pela sua ausência, com excepção daquelas que faziam parte do recheio doméstico de Rui Lourenço o Velho, a que acima me referi, mas essas, de prata, desempenhavam outras funções que não as de mexer os alimentos durante a cozedura ou, sequer, de servirem à mesa: eram um valor a utilizar quando necessário. A falta de inventariação de pequenos objectos já foi notada por vários outros investigadores como, por exemplo, ALEXANDRE-BIDON, Danièle; BECK BOSSARD, Corinne - "La préparation des repas et leur consommation en Forez au XV ${ }^{e}$ siècle d'après les sources archéologiques". in Manger et boire au Moyen Âge. Actes du Colloque de Nice (15-17 octobre 1982). Tome 2 - Cuisine, manières de table, régimes alimentaires. Nice: Centre d'Études medievales de Nice, 1984, p. 63; FRAMOND, Martin de "À la table d'un marchand bourgeois du Puy", p. 111; BRESC-BAUTIER, Geneviève; BRESC, Henri; HERBETH, Pascal - "L'équipement de la cuisine”, p. 49. Vários dos utensílios ausentes, talvez porque facilmente deterioráveis, eram os confeccionados em barro, por sua vez mais facilmente recuperáveis pelos arqueólogos, o que provoca uma grande discordância entre estes espólios e o que consta dos inventários escritos. Veja-se, por exemplo, o que diz STOUFF, Louis - La table provençale. Boire et manger en Provence à la fin du Moyen Âge. Avinhão: Editions A. Barthélemy, 1996, p. 206.

17. As grandes colheres de cozinha, "um pouco frustes", de que fala Anne DIETRICH ("Les petits métiers du bois et les arts de la table à la fin du Moyen Âge". in DIETRICH, Anne ; RAVOIRE, Fabienne (Ed.) - La cuisine et la table dans la France de la fin du Moyen Âge: contenus et contenants du $X I V^{e}$ au XVI ${ }^{e}$ siècle. Turnhout: Brepols, 2009, p. 159) sugerem precisamente um fabrico não profissional, mas antes obra de qualquer "habilidoso".

18. Fundo dos Órfãos de Loulé, p. 108. 
19. Ordenações Afonsinas. Nota de apresentação por Mário Júlio de Almeida Costa, nota textológica por Eduardo Borges Nunes, livro IV. Lisboa: Fundação Calouste Gulbenkian, 1984, tít. LXXXVII, § 1, pp. 325-326. Veja-se a referência ao caso destes órfãos de Loulé em MACHADO, Maria de Fátima - “Os órfãos de Loulé”. in Fundo dos Órfãos de Loulé, p. 13.

20. Registaram-se algumas destas vendas entre a documentação agora em análise: Fundo dos Órfãos de Loulé, pp. 40-41, 74-75, por exemplo.

21. Vejam-se os inventários desta série, Fundo dos Órfãos de Loulé, pp. 27-28, 74-75.

22. Ordenações Afonsinas, liv. IV, tít. LXXXVII, § 2, pp. 326-327. Aí se determinava que todo o tutor, logo que declarado e confirmado pelo juiz dos órfãos, no prazo de dois dias começasse, "peremptoriamente", a fazer o inventário e não interrompesse o trabalho até que tudo estivesse pronto, sob pena de prisão e de restituição ao órfão de toda a perda que dai lhe pudesse advir. Mas a lei nem sempre era cumprida e era até, muitas vezes localmente ignorada.

23. Assim acontecera na vila, a propósito de um outro assunto, o das eleições municipais que os louletanos teimavam em continuar a realizar pelo método até aí costumeiro, mesmo após o rei, no caso D. João I, ter determinado para todo o reino a obrigatoriedade de se fazerem por pelouros. Pode ver-se, sobre este assunto, o trabalho de DUARTE, Luís Miguel - "Eleições municipais no Algarve no início do século XV". in Actas das I Jornadas de história medieval do Algarve e Andaluzia. Loulé: Câmara Municipal de Loulé, 1987, pp. 297-304.

24. PIPONNIER Françoise - "Do lume à mesa: arqueologia do equipamento alimentar no fim da Idade Média”. in FLANDRIN, Jean-Louis; MONTANARI, Massimo (dir.) - História da alimentação. Vol. 2, Da Idade Média aos tempos actuais. Lisboa: Terramar, 2001, p. 130; ALEXANDRE-BIDON, Danièle "Dans les cuisines du Moyen Âge". Dans les cuisines du Moyen Âge: manières de faire, Histoire médiévale, hors serie, n. 8, Nov. 2004-Jan. 2005, p. 45; DIETRICH, Anne - "Les petits métiers du bois", p. 158.

25. ALEXANDRE-BIDON, Danièle - "Dans les cuisines du Moyen Âge", p. 45; ALEXANDRE-BIDON, Danièle; BECK BOSSARD, Corinne - "La préparation des repas", p. 63; LATREMOLIÉRE, Élisabeth "Cuisines et tables royales: les objects témoignent". in COCULA, Annie; COMBET, Michel (Ed.) Chateaux, cuisines et dépendances. Bordéus: Ausonius, 2014, p. 220.

26. Sob este aspecto resulta interessante o trabalho de VALAGÃO, Maria Manuel - "Cozinha mediterrânica no Alentejo - intemporalidade das práticas”. in GÓMEZ MARTÍNEZ, Susana (Ed.) Memória dos sabores do Mediterrâneo. Mértola: Campo Arqueológico / Centro de Estudos Arqueológicos das Universidades de Coimbra e Porto, 2012, pp. 225-234.

27. Abordei este assunto, relativamente aos cereais em GONÇALVES, Iria - "A propósito do pão da cidade na Baixa Idade Média portuguesa". in SILVA, Carlos Guardado da (Ed.) - Turres Veteras IX. História da Alimentação. Torres Vedras: Câmara Municipal de Torres Vedras - Ed. Colibri, 2007, pp. 49-72.

28. Fundo dos Órfãos de Loulé, pp. 21, 42, 57, 62, 74. Estas talhas, de cerâmica muitas delas, podiam ser de produção local (Actas de vereação de Loulé. Séculos XIV-XV, p. 232), ou de importação, como em outras localidades algarvias (COVANEIRO, Jaquelina; CAVACO, Sandra; LOPES, Gonçalo "Importações cerâmicas de Tavira na Baixa Idade Média". Arqueologia Medieval 11 (2010), p. 116).

29. Fundo dos Órfãos de Loulé, pp. 21, 22, 74-75, 87, 106-108. Como outros investigadores verificaram, também os potes se revelaram em Loulé como sendo dos utensílios mais usados na função de armazenamento (TORRES, Cláudio; PALMA, Manuel Passinhas da; REGO, Miguel; MACIAS, Santiago - "Técnicas e utensílios de conservação dos alimentos na Mértola islâmica". Arqueologia Medieval 4 (1996), p. 208). Vejam-se, a título de exemplo, algumas vasilhas para armazenamento de víveres em MACIAS, Santiago - Mértola islâmica. Estudo histórico-arqueologico do bairro da Alcáçova (séculos XII-XIII). Mértola: Campo Arqueológico de Mértola, 1996, p. 110. Embora de época islâmica, as formas mantiveram-se.

30. Fundo dos Órfãos de Loulé, pp. 28, 74-75, 86-90, 106-108. Talvez curiosamente, investigadores que estudaram a Provença, uma região mediterrânica e, assim, quase por definição, vinhateira, 
concluíram pela raridade das reservas desta bebida: BRESC-BAUTIER, Geneviève; BRESC, Henri; HERBETH, Pascal - "L'équipement de la cuisine", p. 47. Pelo contrário, em outros lugares podia ser encontrada uma grande diversidade de contentores destinados ao vinho: GÁZQUEZ ORTIZ, Antonio - La cocina en tiempos del arcipreste de Hita. Madrid: Alianza Editorial, 2002, p. 33.

31. Fundo dos Órfãos de Loulé, pp. 74-75, 86-90, 100-102.

32. Fundo dos Órfãos de Loulé, pp. 21, 42, 57.

33. Fundo dos Órfãos de Loulé, pp. 74-75.

34. Haja em vista os contentores que os arqueólogos assim classificam, cujos fragmentos são por eles exumados com frequência.

35. Fundo dos Órfãos de Loulé, pp. 86-90, 92-95, 100-102, 106-108.

36. Fundo dos Órfãos de Loulé, pp. 27-28, 86-90.

37. BRESC-BAUTIER, Geneviève; BRESC, Henri; HERBETH, Pascal - "L'équipement de la cuisine", p. 47.

38. Vejam-se os autores citados na nota anterior.

39. Cláudio TORRES, Manuel Passinhas da PALMA, Miguel REGO e Santiago MACIAS ("Técnicas e utensílios de conservação", p. 207) pensam que as talhas seriam usadas sobretudo como contentores de água. Em documentação louletana de outro tipo que não os inventários referemse cântaros, vasilhas usadas para o efeito até épocas muito próximas de nós e em púcaros para beber água (Actas de vereação de Loulé. Séculos XIV-XV, pp. 127-128), o que pressupõe existirem em casa reservas desse líquido.

40. Fala-se em Loulé de talhas grandes de pão/cereais (Actas citadas na nota anterior, p. 232).

41. TORRES, Cláudio; PALMA, Manuel Passinhas da; REGO, Miguel; MACIAS, Santiago - "Técnicas e utensílios de conservação", p. 208.

42. Fundo dos Órfãos de Loulé, pp. 22, 25-26, 74-75, 92-95, 106-108. Nas arcas podia guardar-se de tudo, por vezes numa grande mistura de objectos. Quanto a víveres, eram sobretudo os cereais e o pão.

43. Fundo dos Órfãos de Loulé, pp. 74-75 (contendo alguma farinha).

44. Fundo dos Órfãos de Loulé, p. 75 (com trigo).

45. TORRES, Cláudio; PALMA, Manuel Passinhas da; REGO, Miguel; MACIAS, Santiago - "Técnicas e utensílios de conservação", p. 208; CATARINO, Helena - "O castelo de Salir: resultados de exploração dos silos”. Al'-Ulyā 4 (1995), p. 21; MACIAS, Santiago - Mértola islâmica, p. 113.

46. Actas de vereação de Loulé. Séculos XIV-XV, pp. 192-193; MALTEZ, Maria Teresa Nesbitt Rebelo da Silva - Os recursos alimentares no Algarve oriental (século XIV). Lisboa: Faculdade de Ciências Sociais e Humanas, Universidade Nova de Lisboa, 1993. Dissertação de Mestrado, pp. 45-46.

47. Vejam-se MARQUES, A. H. de Oliveira - Introdução à história da agricultura em Portugal. A questão cerealifera durante a Idade Média. 3ª ed., Lisboa: Edições Cosmos, 1978, p. 199; COELHO, Maria Helena da Cruz - "Apontamentos sobre a comida e a bebida do campesinato coimbrão em tempos medievos". in Homens, espaços e poderes (séculos XI-XVI). Vol. I - Notas do viver social. Lisboa: Livros Horizonte, 1990, p. 10; GONÇALVES, Iria - À mesa nas terras de Alcobaça em finais da Idade Média. Alcobaça: DGPC / Mosteiro de Alcobaça, 2017, p. 134.

48. Mencionam-se peneiras em: Fundo dos Órfãos de Loulé, pp. 24, 40-41, 74-75, 86-90, 92-95.

49. Fundo dos Órfãos de Loulé, pp. 40-41.

50. MAZZI, Maria Serena; RAVEGGI, Sergio - Gli uomini e le cose, p. 225; BRESC-BAUTIER, Geneviève; BRESC, Henri; HERBETH, Pascal - "L'équipement de la cuisine", p. 46. Em casas abonadas, como na do rendeiro de Alvorge, nos campos de Coimbra, podia, inclusive, haver mais do que uma: COELHO, Maria Helena da Cruz - "O senhorio crúzio de Alvorge na centúria de Trezentos”. in Homens, espaços e poderes (séculos XI-XVI). Vol. II - Domínio senhorial. Lisboa: Livros Horizonte, 1990, p. 58.

51. CATARINO, Helena - O Algarve oriental durante a ocupação islâmica: povoamento rural e recintos fortificados. Al'-Ulyā 6, vol. II (1997), p. 743; GONÇALVES, Iria - “A alimentação”. in MATTOSO, José 
(dir.) - História da vida privada em Portugal. Vol. I - A Idade Média. Coord. Bernardo Vasconcelos e Sousa. Lisboa: Temas e Debates, 2010, p. 240.

52. Fundo dos Órfãos de Loulé, pp. 22-24, 40-41, 74-75, 86-90, 92-95, 100-102.

53. LUZIA, Isabel - "O espólio cerâmico da cerca do convento". Al'-Ulyā 5 (1996), pp. 62-64. No espólio algarvio estudado por esta investigadora, ela encontrou quinze alguidares, oito dos quais vidrados.

54. Fundo dos Órfãos de Loulé, pp. 74-75.

55. "Transcrição do foral de Loulé”, por Luís Filipe Oliveira, Maria de Fátima Botão e Teresa Rebelo da Silva. in SERRA, Manuel Pedro (Coord.) - O foral de Loulé 1504 - D. Manuel. Loulé: Câmara Municipal de Loulé, 2004, p. 90.

56. Fundo dos Órfãos de Loulé, pp. 22, 74-75.

57. Encontradas em diversas casas louletanas: Fundo dos Órfãos de Loulé, pp. 74-75, 86-90, 92-95, 100-102. Veja-se também ABELLÁN PÉREZ, Juan - El ajuar de las viviendas jerezanas, p. 48.

58. Na documentação em análise este tabuleiro é muito comum, embora com designações diferentes: tabuleiro de tender (Fundo dos órfãos de Loulé, pp. 27-28, 74-75, 86-90, 92-95, 100-102), tabuleiro de pão ao forno ou de levar pão ao forno (Fundo dos Órfãos de Loulé, pp. 27-28, 40-41, 74-75, 86-90, 92-95, 102) ou simplesmente tabuleiro de pôr pão (Fundo dos Órfãos de Loulé, p. 86-90). Veja-se também, como exemplo exterior a nós, STOUFF, Louis - La table provençale, p. 13.

59. Alguns deles tabuleiros seriam efectivamente diferentes e adaptados a cada função, pois se encontram no recheio de algumas casas, concomitantemente, dois tabuleiros ou um tabuleiro e uma tábua designados para funções diferentes: Fundo dos Órfãos de Loulé, pp. 27-28, 74-75, 86-90, 92-95, 100-102.

60. É só em casa de Rui Lourenço o Velho que se encontram estas toalhas (Fundo dos Órfãos de Loulé , pp. 106-108). Por outro lado se aí foram arrolados utensílios mais requintados, faltam alguns dos mais vulgares, mas indispensáveis em qualquer habitação não demasiado pobre. Incluídos aqueles necessários para confeccionar o pão.

61. Sobre este assunto relacionado com o fabrico de pão caseiro pode ver-se GONÇALVES, Iria “A alimentação", p. 240; GONÇALVES, Iria - À mesa nas terras de Alcobaça, pp. 149-150.

62. Encontram-se em quatro dos inventários: Fundo dos Órfãos de Loulé, pp. 40-41, 74-75, 86-90, 106-108. O mesmo panorama foi encontrado em outros lugares, por outros investigadores: HERBETH, Pascal - "Les utensiles de cuisine en Provence médiévale", p. 89; BRESC-BAUTIER, Geneviève; BRESC, Henri; HERBETH, Pascal - "L'équipement de la cuisine”, p. 50; REDON, Odile "Espace, objects et gestes de la cuisine dans la Toscane siennoise el florentine des XIV ${ }^{\mathrm{e}}-\mathrm{XV}^{\mathrm{e}}$ siècles". Médiévales 12 (1987), p. 107.

63. BRESC-BAUTIER, Geneviève; BRESC, Henri; HERBETH, Pascal - "L'équipement de la cuisine", pp. 50, 51; COULET, Noël - "L'équipement de la cuisine à Aix-en-Provence au XVe siècle". Annales du Midi 103 (Jan. 1991), p. 9; STOUFF, Louis - La table provençale, p. 220.

64. Sobre os aspectos relacionados com o fogo na época aqui tratada veja-se, por todos, COLLINAGIRARD, Jacques - Le feu avant les allumettes. Expérimentation et mythes téchniques. Paris: Éditions de la Maison des sciences de l'homme, 1998, pp. 12-29.

65. Essa matéria costumava ser, entre nós, uma planta denominada tordílio, comum em toda a zona mediterrânica (MACIAS, Santiago - Mértola, o último porto do Mediterrâneo. Vol. I. Mértola: Campo Arqueológico de Mértola, 2005, pp. 404-405).

66. Outros investigadores interessados por estes assuntos têm encontrado poucas cremalheiras mas abundância de trempes. Vejam-se, entre outros: PIPONNIER, Françoise - "Do lume à mesa", p. 125; COULET, Noël - "L'équipement de la cuisine”, p. 10; STOUFF, Louis - La table provençale, pp. 203-204.

67. CATARINO, Helena - O Algarve oriental, vol. I, p. 359; TORRES, Cláudio; PALMA, Manuel Passinhas da; REGO, Miguel; MACIAS, Santiago - “Técnicas e utensílios de conservação”, p. 207. 
De qualquer modo devia ser comum a colocação da panela directamente sobre as brasas. Veja-se também LATREMOLIÉRE, Élisabeth - "Cuisines et tables royales", p. 222.

68. E não só nessas habitações mas do mesmo modo em outras bem mais abastadas. Para avaliar a importância deste tipo de cozedura na Idade Média veja-se CICLAIRE, Philippe - Les cuissons alimentaires au Moyen Âge. Paris: L'Hartmattan, 2017, sobretudo os gráficos das pp. 92-93.

69. CONTAMINE, Philippe - La vie quotidienne pendant la guerre de Cent Ans. France et Angleterre (XIVe siècle). [Paris]: Hachette, 1976, p. 219; NADA PATRONE, Anna Maria - Il cibo del ricco ed el cibo del povero. Contributo alla storia qualitativa dell' alimentazione. L'Arga Pedemontana negli ultimi secoli del Medio Evo. Turim : Centro Studi Piemontesi, 1989, pp. 123, 129, 158; COULET, Noël - "Pour une histoire du jardin. Vergers et potagers à Aix-en-Provence: 1350-1450". Le Moyen Âge 73 (1967), p. 244; GONÇALVES, Iria - “Alimentação medieval: conceitos, recursos, práticas”. Actas dos VI Cursos internacionais de Verão de Cascais (5 a 10 de Julho de 1999). Vol. 2, A alimentação. Cascais: Câmara Municipal de Cascais, 2000, p. 39; GONÇALVES, Iria - “A alimentação”, p. 244; GONÇALVES, Iria - À mesa nas terras de Alcobaça, p. 469.

70. No mosteiro de Alcobaça, um dos senhorios eclesiásticos mais ricos de Portugal era assim que se serviam as carnes de vaca e de carneiro (GONÇALVES, Iria - À mesa nas terras de Alcobaça, pp. 444-445), mas até na corte de D. João III era assim que se consumia a carne de vaca, na maioria das vezes (SANTOS, Maria José Azevedo - Jantar e cear na corte de D. João III. Leitura, transcrição e estudo dos livros de cozinha do rei (1524-1542). Vila do Conde - Coimbra: Câmara Municipal de Vila do Conde - Centro de História da Sociedade e da Cultura, 2002, p. 32).

71. Pelo menos os bovinos utilizados na agricultura e nos transportes só deixavam de trabalhar quando o seu rendimento diminuía e eram então levados ao talho. Para citar um exemplo algarvio, lembrarei aquele assunto, tão importante, pelo menos, para ser levado por Silves até ao rei, nas cortes de 1469 , onde ficou expresso que os moradores da cidade compravam bois para lavrarem as suas terras e depois "por seerem uelhos e nom boons os cortam pera comprarem outros" (BOTÃO, Maria de Fátima - Silves, a capital de um reino medievo. Silves: Câmara Municipal de Silves, 1992, pp. 71 e 140). Outros autores o têm verificado como, por exemplo, CARDOSO, João Luís; FERNANDES, Isabel Cristina - "Economia alimentar dos muçulmanos e cristãos no castelo de Palmela: um contributo”. Arqueologia medieval 12 (2012), p. 224; GONÇALVES, Iria - À mesa nas terras de Alcobaça, pp. 225-227; GONÇALVES, Iria - "A colheita régia medieval, padrão alimentar de qualidade (um contributo beirão)". Revista da Faculdade de Ciências Sociais e Humanas 6 (1992-1993), p. 181; CATARINO, Maria Manuela - Na margem direita do Baixo Tejo. Paisagem rural e recursos alimentares (sécs. XIV-XV). Cascais: Patrimonia, 2000, p. 111; STOUFF, Louis - Ravitaillement et alimentation en Provence au XIV et XV siècles. Paris - La Haye: De Gruyter Mouton, 1970, pp. 187-188; FERNANDES, Isabel Cristina Ferreira; CARDOSO, João Luís; DETRY, Cleia - “Cozinhar e comer no castelo medieval de Palmela". in GÓMEZ MARTÍNEZ, Susana (Ed.) - Memória dos sabores do Mediterrâneo. Mértola: Campo Arqueológico / Centro de Estudos Arqueológicos das Universidades de Coimbra e Porto, 2012, p. 121.

72. ALEXANDRE-BIDON, Danièle; BECK BOSSARD, Corinne - "La préparation des repas", p. 64; ARNAUT, Salvador Dias - “A arte de comer em Portugal na Idade Média”, Introdução histórica a $O$ "Livro de Cozinha" da infanta D. Maria de Portugal. Ed. Salvador Dias Arnaut e Giacinto Manuppella. Coimbra: Universidade de Coimbra, 1967, p. LXI; BEIRANTE, Maria Ângela - "Ritos alimentares em algumas confrarias portuguesas medievais". in Territórios do sagrado: crenças e comportamentos na Idade Média em Portugal. Lisboa: Colibri, 2011, p. 192.

73. Fundo dos Órfãos de Loulé, pp. 88-90.

74. No dizer de BOTÃO, Maria de Fátima - "Os eixos estruturantes de uma história". in SERRA, Manuel Pedro (Coord.) - O foral de Loulé 1504 - D. Manuel. Loulé: Câmara Municipal de Loulé, 2004, p. 48.

75. BARROS, Maria Filomena Lopes de - Tempos e espaços de mouros: a minoria muçulmana no reino português (séculos XII a XV). Lisboa: Fundação Calouste Gulbenkian - FCT, 2007, p. 514. 
76. Actas de vereação de Loulé. Séculos XIV-XV, pp. 127-128.

77. A título de exemplo poder-se-ão citar os trabalhos de: LUZIA, Isabel - "O espólio cerâmico da cerca do convento", pp. 60-62; CATARINO, Helena - O Algarve oriental, vol. I, p. 359; CATARINO, Helena - Cerâmicas islâmicas do castelo de Salir. Loulé: Museu Municipal de Arqueologia, 1992, pp. 7-12; GOMES, Mário Varela; GOMES, Rosa Varela; CARDOSO, João Luís - “Aspectos do quotidiano numa casa de Silves durante o século XV". Silves nos Descobrimentos. Xelb: revista de arqueologia, etnologia e história 3 (1996), pp. 43-49.

78. PIPONNIER, Françoise - "Do lume à mesa", p. 125; HERBETH, Pascal - "Les utensiles de cuisine en Provence médiévale”, p. 91; BRESC-BAUTIER, Geneviève; BRESC, Henri; HERBETH, Pascal "L'équipement de la cuisine", p. 51.

79. Fundo dos Órfãos de Loulé, pp. 74-75.

80. Assim acontecia, por exemplo, à mesa dos monges de Alcobaça: GONÇALVES, Iria - À mesa nas terras de Alcobaça, p. 448.

81. Actas de vereação de Loulé. Séculos XIV-XV, pp. 127-128.

82. Fundo dos Órfãos de Loulé, pp. 74-75, 86-90. Adiante voltarei a referir-me a esta loiça.

83. Vejam-se, por exemplo, LUZIA, Isabel - "O espólio cerâmico da cerca do convento”, p. 67; CATARINO, Helena - "O castelo de Salir”, pp. 18-23.

84. Vejam-se, por exemplo: STOUFF, Louis - La table provençale, p. 206; HERBETH, Pascal - "Les utensiles de cuisine en Provence médiévale", p. 91; COULET, Noël - "L'équipement de la cuisine", p. 12; LAURIOUX, Bruno - A Idade Média à mesa. Mem Martins : Publicações Europa-América, 1992, pp. 79-80.

85. STOUFF, Louis - La table provençale, p. 206; HERBETH, Pascal - "Les utensiles de cuisine en Provence médiévale", p. 91.

86. Melhorado o seu sabor com os temperos que deixei citados, o peixe podia servir-se apenas frito em azeite, mesmo na corte de D. Afonso V. Veja-se SANTOS, Maria José Azevedo - "O peixe e a fruta na alimentação da corte de D. Afonso V: Breves notas". in A alimentação em Portugal na Idade Média. Fontes, Cultura, Sociedade. Coimbra: Inatel, 1997, pp. 7-8.

87. LUZIA, Isabel - "O espólio cerâmico da cerca do convento", pp. 62, 64; CATARINO, Helena - "O castelo de Salir”, p. 18; FERNANDES, Isabel Cristina F.; CARVALHO, A. Rafael - “Abordagem arqueológica da Palmela medieval cristã”. Arqueologia medieval 5 (1997), pp. 228-232.

88. Actas de vereação de Loulé. Séculos XIV-XV, pp. 127-128.

89. Fundo dos Órfãos de Loulé, pp. 106-108.

90. Vejam-se, por exemplo: LAURIOUX, Bruno - A Idade Média à mesa, pp. 79-80; HERBETH, Pascal - "Les utensiles de cuisine en Provence médiévale", p. 91; BRESC-BAUTIER, Geneviève; BRESC, Henri; HERBETH, Pascal - "L'équipement de la cuisine", p. 51; PIPONNIER, Françoise - "Do lume à mesa”, p. 126; MAZZI, Maria Serena; RAVEGGI, Sergio - Gli uomini e le cose, p. 214.

91. Podem ver-se, a título de exemplo: COULET, Noël - "L'équipement de la cuisine", pp. 11-12; ABELLÁN PÉREZ, Juan - El ajuar de las viviendas jerezanas, p. 39.

92. Fundo dos Órfãos de Loulé, pp. 92-95.

93. COULET, Noël - "L'équipement de la cuisine", p. 12; GONÇALVES, Iria - À mesa nas terras de Alcobaça, p. 446; BRESC-BAUTIER, Geneviève; BRESC, Henri; HERBETH, Pascal - "L'équipement de la cuisine", p. 51.

94. Foram também estes aspectos que Juan ABELLÁN PÉREZ (El ajuar de las viviendas jerezanas, p. 39) encontrou em profusão e que Guillermo ROSSELLÓ BORDOY (El ajuar de las casas andalusíes. Málaga: Editorial Sarriá, 2002, p. 26) refere para as casas muçulmanas da Andaluzia.

95. LOPES, Fernão - Crónica de D. João I. Ed. prefaciada por António Sérgio e preparada por M. Lopes de Almeida e A. de Magalhães Basto, vol. I. Porto: Livraria Civilização, 1945, cap. LXXV, pp. 146-147.

96. BEIRANTE, Maria Ângela - "Ritos alimentares”, p. 190. 
97. GONÇALVES, Iria - "Dant vitam maiordomo de quali habuerint. Apontamentos sobre um direito senhorial à luz dos inquéritos afonsinos". in Por terras de Entre-Douro-e-Minho com as Inquirições de Afonso III. Porto: CITCEM - Edições Afontamento, 2012, p. 170.

98. BOTÃO, Maria de Fátima - A construção de uma identidade urbana, p. 187.

99. BOTÃO, Maria de Fátima - A construção de uma identidade urbana, pp. 202-207.

100. DUARTE, Luís Miguel - “Quinhentos anos depois". in SERRA, Manuel Pedro (Coord.) - o foral de Loulé 1504 - D. Manuel. Loulé: Câmara Municipal de Loulé, 2004, p. 11.

101. Vejam-se, entre outros trabalhos: ALEXANDRE-BIDON, Danièle - "Dans les cuisines du Moyen Âge", p. 45; COULET, Noël - "L'équipement de la cuisine", pp. 8-9; HERBETH, Pascal - "Les utensiles de cuisine en Provence médiévale", p. 90; REDON, Odile - "Espace, objects et gestes de la cuisine", p. 107; STOUFF, Louis - La table provençale, p. 202.

102. Fundo dos Órfãos de Loulé, pp. 22, 25-26, 74-75, 86-90, 106-108.

103. Dado que as plantas condimentares são todas aquelas cujas folhas, caules, bolbos, flores, sementes se utilizam na culinária para melhorar o sabor dos alimentos (VALAGÃo, Maria Manuel; SILVA, Joana Gomes da - "As tradições alimentares". in VALAGÃO, Maria Manuel (Org.) - Tradição e inovação alimentar: dos recursos silvestres aos itinerários turísticos. Lisboa: Colibri - INIAP, 2006, p. 95), a sua variedade é enorme, com algumas pequenas diferenças de região para região, mas muitas delas, sobretudo na forma de cultívares, podendo ser encontradas em todo o lado.

104. FERREIRA, Maria Elvira; SARAIVA, Isabel - "Plantas da flora local com valor alimentar e aromático". in VALAGÃO, Maria Manuel (Org.) - Tradição e inovação alimentar: dos recursos silvestres aos itinerários turísticos. Lisboa: Colibri - INIAP, 2006, pp. 29-38, dão-nos uma longa lista dessas plantas.

105. Forais manuelinos do reino de Portugal e do Algarve conforme o exemplar do Arquivo Nacional da Torre do Tombo de Lisboa. Ed. Luiz Fernando de Carvalho Dias. Vol. 3 - Entre Tejo e Odiana. Lisboa: Edição do Autor, 1965, p. 3.

106. “Transcrição do foral de Loulé”, p. 87.

107. Na sessão camarária de 11 de Agosto de 1403 foi acordado que o concelho emprestasse duzentos reais a Turíbio Eanes, homem pobre mas considerado capaz de fazer o que se propunha, para ele comprar semente de mostarda e "fazer e dar a dicta mostarda ao Concelho" (Actas de vereação de Loulé. Séculos XIV-XV, p. 139).

108. Como um exemplo que me parece ser muito significativo, veja-se o almofariz, talhado em mármore, de paredes e fundo espessos mas cuja parte central do fundo desapareceu com o uso, almofariz recuperado em Silves por GOMES, Mário Varela; GOMES, Rosa Varela; CARDOSO, João Luís - "Aspectos do quotidiano numa casa de Silves", p. 59.

109. Fundo dos Órfãos de Loulé, pp. 86-90.

110. CORRIENTE, Federico - Diccionario de arabismos y voces afines en iberoromance. Madrid: Gredos, 1999, p. 238. Seria talvez semelhante àqueles de que fala Guillermo ROSSELLÓ BORDOY (El ajuar de las casas andalusíes, pp. 25-26) como sendo imprescindíveis nas habitações muçulmanas da Andaluzia. A mesma palavra pela qual ele é designado no inventário mostra bem as suas origens orientais. Também Santiago MACIAS (Mértola islâmica, p. 109) nos mostra imagens de alguns desses fogareiros.

111. ARRIVÉ, Nadège - "Le vin en France au XVI ${ }^{\mathrm{e}}$ siècle. Aspects du vin: productions, usages et pratiques culinaires". in VIALLON-SCHONEVELD, Marie (Ed.) - Le boire et le manger au XVI ${ }^{e}$ siècle. Actes du XI e colloque du Puy-en-Valay. Saint-Étienne: Publications de l'Université de Saint-Étienne, 2004, p. 184.

112. Já em outra ocasião me referi ao assunto: GONÇALVES, Iria - À mesa nas terras de Alcobaça, p. 467. Veja-se também a bibliografia aí citada.

113. BOTÃO, Maria de Fátima - A construção de uma identidade urbana, pp. 222-223.

114. MARTINS, Luísa Fernanda Guerreiro - Contributos para a história da alimentação algarvia a partir das actas de vereação do concelho de Loulé (1384-1488). Faro: Direção Regional de Cultura do 
Algarve, 2016, p. 70. Veja-se também FERREIRA, Maria Valentina Garcia - "A fruta de Loulé na Europa medieval: análise de um manuscrito do século XV”. Al'-Ulyā 9 (2003), pp. 215-239.

115. Veja-se o que atrás ficou dito.

116. O que era uma situação muito comum, também fora de Portugal. Podem ver-se entre muitos outros trabalhos: FRAMOND, Martin de - "À la table d'un marchand bourgeois", p. 107; PIPONNIER, Françoise - "Do lume à mesa”, p. 129; MAZZI, Maria Serena; RAVEGGI, Sergio - Gli uomini e le cose, p. 216.

117. GONÇALVES, Iria - “A alimentação”, p. 252; STOUFF, Louis - La table provençale, p. 215; FRAMOND, Martin de - “À la table d'un marchand bourgeois”, p. 108.

118. Fundo dos Órfãos de Loulé, pp. 40-41, 86-90, 100-102.

119. Fundo dos Órfãos de Loulé, pp. 106-108.

120. GONÇALVES, Iria - “A alimentação”, p. 252.

121. MARQUES, A. H. de Oliveira - A sociedade medieval portuguesa. Aspectos de vida quotidiana, 6." ed., Lisboa: Esfera dos Livros, 2010, p. 38; ABELLÁN PÉREZ, Juan - El ajuar de las viviendas jerezanas, p. 59.

122. GONÇALVES, Iria - “A alimentação”, pp. 252-253.

123. Fundo dos Órfãos de Loulé, p. 37.

124. Federico CORRIENTE (Diccionario de arabismos, p. 208) apresenta para este vocábulo o significado de capa mourisca. Todavia, neste caso, uma vez que expressamente ficou indicado tratar-se de uma peça a usar na mesa, só pode ser uma espécie de mantel. $\mathrm{O}$ autor regista para a língua portuguesa as formas alquicé e alquicer.

125. Fundo dos Órfãos de Loulé, pp. 106-108.

126. Fundo dos Órfãos de Loulé, pp. 88-90.

127. A distinção entre pratel e o talhador grande não é muito clara. Penso que este último se destinava, de preferência, a que sobre ele se "talhassem", se trinchassem as carnes de que cada um dos comensais se servia e os pratéis a receberem os alimentos cortados em pedaços e, eventualmente, envoltos no molho que resultara da preparação culinária utilizada. Muitos deles eram confeccionados em estanho - e assim acontecia em Loulé -, material caro que não se compadecia com golpes que o trinchar alimentos neles depositados lhes poderiam proporcionar. Nas casas de grande proeminência podiam mesmo existir pratéis apenas para sobre eles se colocarem as jarras de serviço (veja-se ARNAUT, Salvador Dias - "A arte de comer em Portugal na Idade Média", p. LXXVII).

128. Fundo dos Órfãos de Loulé, pp. 106-108.

129. Fundo dos Órfãos de Loulé, pp. 86-90, 92-95, 100-102, 106-108.

130. Fundo dos Órfãos de Loulé, pp. 40-41, 92-95.

131. Fundo dos Órfãos de Loulé, pp. 86-90.

132. Fundo dos Órfãos de Loulé, pp. 74-75.

133. Fundo dos Órfãos de Loulé, pp. 22, 74-75, 86-90.

134. “Transcrição do foral de Loulé”, p. 97.

135. Forais manuelinos do reino de Portugal e do Algarve, Entre Tejo e Odiana, pp. 3-4.

136. Como exemplo poderei citar um pichel de Málaga constante do recheio da casa do rendeiro da granja de Alvorge, pertencente ao mosteiro de Santa Cruz de Coimbra, já atrás referido (COELHO, Maria Helena da Cruz - "O senhorio crúzio de Alvorge”, p. 58).

137. ARNAUT, Salvador Dias - "A arte de comer em Portugal na Idade Média", p. LXXXI.

138. ABELLÁN PÉREZ, Juan - El ajuar de las viviendas jerezanas, pp. 59-60, 63, 66; COVANEIRO, Jaquelina; CAVACO, Sandra; LOPES, Gonçalo - "Importações cerâmicas de Tavira", p. 115, referem peças dessa proveniência por elas recuperadas em Tavira.

139. Pelo menos para os talhadores sabe-se que podiam ser redondos ou quadrangulares - o que também a iconografia documenta - e até, eventualmente, terem um pé (veja-se, para estes últimos, ABELLÁN PÉREZ, Juan - El ajuar de las viviendas murcianas, p. 37). 
140. Quando nestes como em outros textos semelhantes se referem bacios ou bacias sem mais explicitações, é impossível saber se o seu uso se restringia à cozinha, e mesmo aí que uso se lhes dava, ou se se alargava à mesa. Penso que algumas destas alfaias seriam multifuncionais, ao menos nas habitações mais pobres. Todavia, quando confeccionadas em materiais mais ricos, é sabido que serviam à mesa.

141. GONÇALVES, Iria - “A alimentação”, p. 253.

142. Fundo dos Órfãos de Loulé, pp. 74-75, 86-90.

143. VITERBO, Joaquim de Santa Rosa de - Elucidário das palavras, termos e frases que em Portugal antigamente se usaram e que hoje regularmente se ignoram. Ed. crítica de Mário Fiúza, vol. I. Porto: Civilização, 1965, p. 436.

144. ABELLÁN PÉREZ, Juan - El ajuar de las viviendas jerezanas, p. 67.

145. Fundo dos Órfãos de Loulé, pp. 25-26, 27-28, 74-75.

146. Fundo dos Órfãos de Loulé, pp. 27-28.

147. Fundo dos Órfãos de Loulé, pp. 40-41, 74-75, 86-90, 92-95, 100-102, 106-108. Para esta como para outras alfaias de cozinha e mesa pode ver-se MACHADO, Maria de Fátima - "Os órfãos de Loulé e a gestão do seu património nos séculos XV e XVI”. Al'-Ulyā 18 (2017), quadro da p. 57.

148. Talvez aquelas que não receberam do escrivão qualquer qualificativo: Fundo dos Órfãos de Loulé, pp. 86-90, 92-95.

149. Fundo dos Órfãos de Loulé, pp. 106-108. Considerei a albarrada um artefacto de servir à mesa, na medida em que Rafael Bluteau a define como infusa ou pichel (cit. em $O$ "Livro de Cozinha" da infanta D. Maria de Portugal. Ed. por Salvador Dias Arnaut e Giacinto Manuppella. Coimbra: Universidade de Coimbra, p. 170). Serviria também na cozinha e é aí que o receituário da infanta a dá a conhecer, num prato feito à base de ovos, polvilhados no final com açúcar e canela ( $O$ "Livro de Cozinha", p. 60).

150. ARNAUT, Salvador Dias - "A arte de comer em Portugal na Idade Média”, p. LXXVIII.

151. Fundo dos Órfãos de Loulé, pp. 86-90, 106-108.

152. Fundo dos Órfãos de Loulé, p. 101.

153. Fundo dos Órfãos de Loulé, pp. 106-107. Adiante voltarei a referir-me a este utensílio.

154. Fundo dos Órfãos de Loulé, pp. 25-26, 86-90, 106-108.

155. Fundo dos Órfãos de Loulé, pp. 40-41.

156. Aos primeiros, com algumas dúvidas, foi-lhes atribuído o sentido de tabuleiros (ver ARNAUT, Salvador Dias - "A arte de comer em Portugal na Idade Média”, p. LXXVII); charão significava, é certo que em época muito posterior, tanto quanto sei, um tabuleiro de metal, em regra decorado com pinturas.

157. Fundo dos Órfãos de Loulé, pp. 74-75, 92-95.

158. Fundo dos Órfãos de Loulé, pp. 25-26. Sobre a palavra cunca veja-se VARELA SIEIRO, Xaime Léxico cotián na Alta Idade Media de Galicia: o enxoval. A Coruña: Ediciís do Castro, 2003, pp. 216-217.

159. “Transcrição do foral de Loulé”, p. 90.

160. MARQUES, A. H. de Oliveira - A sociedade medieval portuguesa, p. 40; GONÇALVES, Iria - “A alimentação", p. 252; BRESC-BAUTIER, Geneviève; BRESC, Henri; HERBETH, Pascal "L'équipement de la cuisine", p. 54; HERBETH, Pascal - "Les utensiles de cuisine en Provence médiévale", p. 92.

161. Actas de vereação de Loulé. Séculos XIV-XV, pp. 127-128. Talvez semelhantes aos apresentados por Helena CATARINO (Cerâmicas islâmicas do castelo de Salir, pp. 13-14), pequenos púcaros com uma só asa, fabricados em cerâmica.

162. Fundo dos Órfãos de Loulé, pp. 86-90.

163. DIETRICH, Anne - "Les petits métiers du bois", p. 159 e também PIPONNIER, Françoise - "Do lume à mesa", p. 130.

164. Fundo dos Órfãos de Loulé, p. 109.

165. LATREMOLIÉRE, Élisabeth - “Cuisines et tables royales”, p. 220. 
166. DIETRICH, Anne - "Les petits métiers du bois", nota 163, p. 160; MARQUES, A. H. de Oliveira A sociedade medieval portuguesa, p. 40, como exemplos.

167. MARQUES, A. H. de Oliveira - A sociedade medieval portuguesa, p. 40; STOUFF, Louis - La table provençale, p. 220; LAURIOUX, Bruno - A Idade Média à mesa, p. 96.

168. Veja-se o que dizem para Itália MAZZI, Maria Serena; RAVEGGI, Sergio - Gli uomini e le cose, p. 216.

169. STOUFF, Louis - La table provençale, p. 220.

170. GONÇALVES, Iria - “A alimentação”, p. 252; GÁZQUEZ ORTIZ, Antonio - La cocina en tiempos del arcipreste de Hita, p. 38.

171. Pode lembrar-se aquela casa louletana em que ficou declarado um copo. A ser esta, na verdade, toda a alfaia do género, os diferentes membros da família tinham que servir-se com o mesmo utensílio e, eventualmente, também qualquer outro conviva que com ela partilhasse a refeição. A não ser que o copo estivesse reservado para o chefe de família ou fosse oferecido a um convidado de prestígio, enquanto todos os outros continuavam a servir-se directamente do pichel.

172. Veja-se LAURIOUX, Bruno - A Idade Média à mesa, p. 96.

173. Fundo dos Órfãos de Loulé, pp. 106-108.

174. LAURIOUX, Bruno - A Idade Média à mesa, p. 96.

175. LAURIOUX, Bruno - A Idade Média à mesa, p. 96.

176. Fundo dos Órfãos de Loulé, p. 107.

177. Veja-se, entre os exemplos apontados por Salvador Dias ARNAUT ("A arte de comer em Portugal na Idade Média", p. LXXVIII), a existência de gomis e pichéis de "água às mãos".

178. MARQUES, A. H. de Oliveira - A sociedade medieval portuguesa, p. 39. Veja-se este assunto mais desenvolvidamente em GONÇALVES, Iria - “A alimentação", pp. 257-259.

179. Fundo dos Órfãos de Loulé, pp. 106-108.

180. O foral quinhentista de Loulé refere-se concretamente a água rosada e água de flor de laranja, como já atrás ficou lembrado. Eram usadas na condimentação dos pratos, nos cuidados de beleza e até nos medicamentos, mas podiam também ser usadas à mesa, em ocasiões especiais, entre as famílias mais proeminentes.

181. Foi essa uma forma de suprir faltas que chegou bem perto dos nossos dias. Verificada, por exemplo, para os séculos XIII e XIV por LE ROY LADURIE, Emmanuel - Montaillou, village occitan de 1294 a 1324. Paris: Gallimard, 1975, p. 69.

\section{RESUMOS}

Os documentos do chamado Fundo do juiz dos órfãos de Loulé, do Arquivo Histórico desta cidade, são peças raras no contexto medieval português, com enorme interesse para o estudo da orfandade medieval. Apesar de produzidos para salvaguardar o interesse dos órfãos e para acompanhar a maneira como os tutores respectivos administravam os seus bens, ou prestavam contas dessas tutelas, eles revelam de modo igual imensas outras facetas do viver medieval. Dez deles, redigidos ao longo de setenta anos, entre 1408 e 1479, são aqui utilizados para recuperar os utensílios de uso comum na cozinha e na mesa medieval, associados à armazenagem, à confecção e ao consumo dos alimentos. Não esquecendo a natureza e os limites dos registos escritos, mas conjugando os informes destes com os dados da Arqueologia e da Etnografia, obteve-se um 
panorama bastante coerente, a que não faltam observações sobre o significado social da escassez de alfaias em certos agregados familiares, ou sobre a distinção denunciada pela qualidade e pela raridade de alguns outros utensílios.

The documents of the so-called Fund of the judge of the orphans of Loulé, from the Historical Archive of this city, are rare pieces in the Portuguese medieval context, with enormous interest for the study of medieval orphanage. Although produced to safeguard the interest of the orphans, and to follow the way the respective guardians administered their property or held accounts of these tutelages, they equally reveal many other facets of medieval living. Ten of them, drafted over seventy years, between 1408 and 1479, are used here to recover the utensils used in the kitchen and at the medieval table, associated with the storage, cooking and consumption of food. Not forgetting the nature and limits of the written records, but combining their reports with archaeological and ethnographical data, a fairly coherent picture was obtained, with observations on the social significance of the shortage of equipments in certain households, or on the distinction denounced by the quality and rarity of some other kitchenware.

\section{ÍNDICE}

Keywords: Household appliances; Art of Fire; Food; kitchenware; Archeology; Ethnography

Palavras-chave: Alfaias domésticas; Arte do Fogo; Alimentação; Arqueologia; Etnografia

\section{AUTOR}

\section{IRIA GONÇALVES}

Instituto de Estudos Medievais, Faculdade de Ciências Sociais e Humanas, Universidade Nova de Lisboa, 1069-061, Lisboa, Portugal

iem.geral@fcsh.unl.pt

https://orcid.org/0000-0002-9793-1287 